\title{
Unlocking the Deadlocks?
}

GMOs, Science and the Reform of the Legal

Framework

Inka Eberhardt, Daniel Limberg, Dorottya Liptai, Nele Rosenstock, Lucas Unterberg, Trebor Wagner 
$\left.254\right|^{\text {RITUR }}$ 


\section{Table of Contents}

1. Introduction

2. Research Approach and Methodology

260

3. The Former Authorization Procedure and the Importance of Science

3.1 The Authorization Procedure in Practice - the First Deadlock

4. Science as Solution to the First Deadlock?

4.1 The Unreliability of Scientific facts

268

4.2 Science's role in risk assessment

270

4.3 Science's role in Risk Management

271

5. The Second Deadlock: Disagreement on the Proposal

5.1 The Proposal: A Solution to the Deadlock?

274

5.2 EU Internal Market Compatibility

5.3 Compatibility with WTO Regulation

6. Unlocking the Deadlocks?

6.1 Inclusion of Indicative List of Grounds in Art. 26b

6.2 The Assessment Committee

284

6.3 Possible Assessment Practices

7. Accommodating Diversity - The Broader Picture

8. Conclusion 
$\left.256\right|^{\text {RITUR }}$ 


\title{
1. Introduction
}

\author{
Hydra |'hīdrə|- "In Greek mythology, a many-headed snake \\ whose heads grew again as they were cut off, ... in figurative \\ usage, a thing which is hard to overcome [or resist because \\ of its pervasive or enduring quality] or its many aspects".'
}

The hydra is in many ways a well-working allegory for the numerous conflicts the EU has been facing in the GMO authorization process, and in particular regarding the complex deadlocks in the authorization of GMOs for cultivation. In the 1990s, heavy pressure at the international level ${ }^{2}$ caused the responsible EU decision-makers to establish a regulatory framework $^{3}$ and the European Food Safety Authority (EFSA) ${ }^{4}$ to finally resolve their struggles with the de facto moratorium on GMO authorization. Unfortunately, this solution to the conflicts and struggles with GMO authorization did not prove to be sufficient. Even worse, the EU decision-makers faced what we call the first deadlock. It originated from the continuous bans of GMOs that Member States imposed with the safeguard clause, ${ }^{5}$ now in particular on GMO cultivation. ${ }^{6}$ As with the Hydra's many heads which are growing back numerously every time one head is cut off, each time one issue was solved in the GMO authorization process, numerous other problems came up.

1 Oxford University Press: Hydra; retrieved on 13/06/2013: http://www.oxfordreference.com/view/10.1093/ oi/authority.20111017150154589? rskey=3KCgXF\&result=8\&q= hydra.

2 For more information see: Caroline Henckels, “GMOs in the WTO: A Critique of the Panel' Reasoning in the EC - Biotech", 7, Melbourne Journal of International Law (2009), pp. 279 et sqq; Jacqueline Peel, Rebecca Nelson and Lee Godden, "GMO Trade Wars: The Submissions in the EC - GMO Dispute in the WTO", 6, Melbourne Journal of International Law (2005), pp.141 et sq9.; Antonia Eliason, "Science versus Law in WTO Jurisprudence: The (Mis)interpretation of the Scientific Process and the (In)sufficiency of Scientific Evidence in EC-Biotech", 41, International Law and Politics (2009), 41, pp.341-406; David Winickoff, Sheila Jasanoff, Lawrence Busch et al., "Adjudicating the GM Food Wars: Science, Risk, and Democracy in World Trade Law", 30, The Yale Journal of International Law (2005), pp.82 et sqq.

3 European Parliament and Council Directive 2001/18/EC on the deliberate release into the environment of genetically modified organisms and repealing Council Directive 90/220/EEC, OJ $2001 \mathrm{~L} 106$.

4 European Parliament and Council Regulation (EC) No 178/2002 on the general principles and requirements of food law, establishing the European Food Safety Authority and laying down procedures in matters of food safety, OJ L 031, 1.2.2002, p.1.

5 Directive 2001/18/EC, supra note 3, Art. 23.

6 Austria, France, Greece, Hungary, Germany and Luxembourg, from: DG Health and Consumers, "Rules on GMOs in the EU - Ban on GMO cultivation", no date, available on the Internet at http://ec.europa.eu/food/food/ biotechnology/gmo_ban_cultivation_en.htm (last accessed on 14 June 2013). 
When over time the new directive and agency proved not be the solution to the many conflicts and as there was no sign that GMO-opposing Member States would finally stop the banning, Member States from both camps - anti- and pro-GMO - instrumentalised the Commission ${ }^{7}$ to end the conflict on GMO authorization. The Commission attempted to do so by drafting a proposal, ${ }^{8}$ which arguably gave the Member States more freedom in deciding whether or not to cultivate GMOs in their territory. ${ }^{9}$ Thereby the Commission expected to accelerate the general authorization procedure for GMOs, as anti- GMO Member States could on the one hand agree on authorization of GMOs at the EU level, but also had the opportunity to ban their cultivation on national territory. Irrespective of the Commission's attempt to solve the conflict and give the Member States more freedom, the proposal did not succeed in solving the deadlock. It was heatedly debated by EU officials and stakeholders, ${ }^{10}$ partly amended by the European Parliament (EP) and has not been adopted yet, as a blocking minority in the Council exists. We label this

7 Council of the European Union, “Genetically Modified Organisms - A Way Forward”; 23 June 2009, available on the Internet at: http://register.consilium.europa.eu/pdf/en/og/st11/st11226-reo1.enog.pdf (last accessed on 14 June 2013). Note submitted by the Austrian delegation, supported by Bulgaria, Ireland, Greece, Cyprus, Latvia, Lithuania, Hungary, Malta, Poland and Slovenia. Also referring to the Netherlands: "The Netherlands delegation came up with a declaration et the last Environment Council on 2 March 2009 calling for Member States to have the right to decide for themselves on the cultivation of GMOs. The delegations cited above appreciate this initiative and are willing to develop et further in order to find a satisfactory long-term solution" (p.2). "On June 24, 2009 a number of Member States (namely Austria, Bulgaria, Ireland, Greece, Cyprus, Latvia, Lithuania, Luxembourg, Hungary, Malta, the Netherlands, Poland and Slovenia) requested that the Commission give Member States the freedom to cultivate plants based on "relevant socio-economic aspects". On July 13, 2010 the EU Commission announced a proposal for the addition of one article to Directive 2001/18/EC, which would explicitly allow Member States to restrict or prohibit cultivation of GMOs on their territories" Shane H. Morris \& Charles Spillane, "EU GMO Crop Regulation: A Road to Resolution or a Regulatory Roundabout?", 4, European Journal of Risk Regulation (2010), pp.359 et sq9., et p.365.

8 Commission Proposal for a Regulation of the European Parliament and of the Council Amending Directive 2001/18/ EC as regards the possibility for the Member States to restrict or prohibit the cultivation of GMOs in their territory, $\operatorname{COM}(2010) 380$ final, $\operatorname{COM}(2010) 4822$ final.

9 EurActiv, "EU wants to put GMO dispute to an end", 5 November 2010, available on the Internet at http:// www.euractiv.com/cap/eu-wants-put-gmo-dispute-news-496059 (last accessed on 13 June 2013); EurActiv, "EU move to break GM deadlock could sow discord", 5 November 2012, available on the Internet at http:// www.euractiv.com/cap/eu-move-break-gm-deadlock-sow-di-news-495753 (last accessed on 13 June 2013).

EurActiv, “EU GMO proposals draw widespread criticism”, 5 November 2012, available on the Internet at http:// www.euractiv.com/cap/eu-gmo-proposals-draw-widespread-news-496263 (last accessed on 13 June 2013).

11 Corrine Lepage, Report on the proposal for a regulation of the European Parliament and of the Council amending Directive 2001/18/EC as regards the possibility for the Member States to restrict or prohibit the cultivation of GMOs in their territory (COM (2010)0375 - C/-0178/2010 - 2010/O208(COD)), Report issued by European Parliament on 20 April 2011. 
situation the 'second deadlock' - namely the deadlock on the solution of the first deadlock. After a couple of years of silence on this situation, the proposal and the whole deadlock situation suddenly became news again, when the Commission announced the revival of the talks ${ }^{12}$ and Monsanto, one the biggest GM producing companies, threatened to leave the European market in 2013. ${ }^{13}$

GMO authorization in the EU was never an easy topic, partly because the European public is not very fond of the idea of having GM-food on their table. ${ }^{14}$ Therefore, not only the heads of the hydra, but also the hydra itself can be compared to the GMO authorization process. In Greece mythology, the hydra was hated by the public as it murdered the farmers' cattle at night. Unfortunately, up to now there was no Herakles in the EU, being able to find a solution on how to solve the deadlocks in GM- authorization. As there is no complete solution evident at the moment, we investigate to what extent the two deadlocks might be unlocked, also in light of the high prevalence of the topic in the news. Even though we are aware of the manifold aspects surrounding GM-authorization and cultivation, we aim to provide an overview for a broad scholarly public, not only on how the two deadlock arose and what were the exact issues at stake but also regarding the many heads of the hydra - namely the many issues decision-makers need to take into account - when trying to unlock the deadlocks. After explaining our research approach and methodology, our analysis first provides a general overview on the regulatory framework on GMOs. By describing the problems of authorization in practice, we investigate the first deadlock. Subsequently, some of the Hydra's heads are cut off by means of analysing whether or not science is the solution to the first deadlock. The fourth section presents the Commission's proposal to solve the deadlock, which is subsequently analysed on its legal viability regarding EU and WTO legislation. It is then attempted to solve the deadlock, or at least to provide some ideas on how to move a step towards solving it. Before concluding, we embed our proposal in the latest state-of-the-art academic literature.

12 Reuters, "EU seeks to revive talks on GMO crop cultivation", 22 January 2013, available on the Internet at http://uk.reuters.com/article/2013/01/22/eu-gmo-cultivation-idUKL6NoARCX620130122 (last accessed on 6 June 2013).

13 EurActiv, "Disgruntled GMO firms start pulling et of EU market”, 25 January 2012, available on the Internet at http://www.euractiv.com/cap/disgruntled-gmo-firms-start-pull-news-510378 (last accessed on 12 June 2013).

14 TNS Opinion \& Social, "Special Eurobarometer 341 on Biotechnology", October 2010, Document requested and coordinated by the European Commission DG Communication, available on the Internet at http://ec.europa.eu/public_opinion/archives/ebs/ebs_341_en.pdf (last accessed 14 June 2013); Leonie Sontheimer, "Märsche mahnen Monsanto", Die Tageszeitung, 25 May 2013, available on the Internet at http://www.taz.de/!11680o/ (last accessed on 6 June 2013). 


\section{Research Approach and Methodology}

Our article integrates itself in a line of interdisciplinary research on risk regulation (e.g.: Jasanoff ${ }^{15}$, Fisher et al. ${ }^{16}$, Everson \& Vos, Van Asselt ${ }^{17}$, Versluis \& Vos $^{18}$, Van Asselt \& Vos ${ }^{19}$. Risk regulation has an impact on various domains such as environment, trade, jurisdiction and the public and is therefore a highly complex issue. As the topic of our article overarches numerous domains such as trade in a globalized world, society, science and technology as well as legal sciences, an interdisciplinary approach is not only suitable but also thought provoking to answer the question of unlocking the deadlocks. With the words of Van Asselt and Vos "interdisciplinary research in law and social sciences allows for an improved examination of regulatory arrangements" ${ }^{20}$ and according to us also stimulates new ideas.

Whereas the former is evident in the comprehensive analytical part of our article, the latter is especially visible in the section of our solution to the deadlocks.

By combining a social sciences approach with a legal analysis, we aim at answering our research question as precise and thorough as possible. As pointed out by Van Asselt and Vos, it strengthens and completes the analysis when social scientists take account of the legal context and lawyers examine the answers of social sciences with the lenses of their educational background. Since we investigate a deadlock caused by societal, scientific and legal problems, it is not only interesting but also necessary to examine the conflict from several points of view.

Whereas the beginning of our article presents an opportunity for legal scholars to grasp the issues at stake from a social sciences point of view, later sections on the legal analysis

15 Sheila Jasanoff, Designs on Nature: Science and Democracy in Europe and the United States, (USA: Princeton University Press, 2005).

16 Elizabeth Fisher, Judith Jones \& René von Schomberg, (eds), Implementing The Precautionary Principle Perspectives and Prospects, (UK: Edward Elgar Publishing Limited, 2006).

17 Michelle Everson \& Ellen Vos, "The Scientification of Politics and the Politicisation of Science", in Michelle Everson \& Ellen Vos (eds.), Uncertain Risks Regulated. Facing the Unknown in National, EU and International Law. (London and New York: Routledge, 2009), pp.1-17. legal and social science perspectives, (London, UK: Routledge, 2013).

19 Marjolein B.A. Van Asselt \& Ellen Vos, "Wrestling with Uncertainty: EU Regulation of GMOs and the Uncertainty Paradox", 11, Journal of Risk Research, 2008, pp. 281-300.

20 Marjolein B.A. Van Asselt, Tessa Fox, Esther Versluis \& Ellen Vos, "Regulating Innovation, Trade and Uncertain Risks", in Marjolein B.A. Van Asselt, Esther Versluis, \& Ellen Vos (eds.), Balancing between trade and risk : Integrating legal and social science perspectives, (London, UK: Routledge, 2013), pp.247 et sq9. at p.248.

Van Asselt et al., Balancing between Trade and Risk, supra note 20, at p.248. 
of the proposal aim at providing the social scientist with a complete and understandable overview of possible conflicts in the legal domain. ${ }^{22}$ Moreover, our policy proposal, developed on knowledge of both fields - social sciences and legal studies - shows that the deadlocks might only be unlocked if both fields carefully listen to each other and take into account each others' difficulties. It is of utter importance that on the one hand "legal scholars remind social scientists to take serious account of legal frameworks and realities". On the other hand, legal scholars need "to consider the societal dimensions of risk controversies and trade conflicts as wel as the socially constructed nature of expertise".

Therefore, we draw conclusions from close reading of primary sources such as EU and WTO legislation, case law as well as newspaper articles from different Member States, but also scholarly research done in the same context. ${ }^{24}$ In order to move a step forward towards unlocking the deadlocks, the legal framework of a particular risk regulation is examined with lenses from political and social sciences (as has been done inter alia by: Fox et al. $^{25}$, Van Asselt ${ }^{26}$ ) as well as scholarly work by science and technology scholars (for consultation see: Fox et al., Wickson \& Wynne ${ }^{27}$, Devos et al. ${ }^{28}$ ).

22 Ibid.

23 Ibid.

24 for reference see: Maria Weimer, "What Price Flexibility? - The Recent Commission Proposal to Allow for National "Opt-Outs" on GMO Cultivation under the Deliberate Release Directive and the Comitology Re form Post-Lisbon", 4, European Journal of Risk Regulation (2010), pp.345 et sq9.; Fern Wickson \& Brian Wynne, "The Anglerfish deception - The light of proposed reform in the regulation of GM crops hides underlying problems in EU science and governance", 13, European Molecular Biology Organization Reports, (2012), pp.100 et sqq.

25 Tessa Fox, Esther Versluis \& Marjolein B.A. Van Asselt, "Regulating the Use of Bisphenol A in Baby and Children's Products in the European Union: Trade Implications of an Uncertain Risk" in: in Marjolein B.A. van Asselt, Esther Versluis, \& Ellen Vos (eds.), Balancing between trade and risk : Integrating legal and social science perspectives, (London, UK: Routledge, 2013), pp.147 et sqq.

26 Van Asselt et al., Balancing between Trade and Risk, supra note 20.; Marjolein B.A. Van Asselt, Ellen Vos \& B. Rooijackers, "Science, Knowledge and Uncertainty in EU Risk Regulation", in Michelle Everson \& Ellen Vos (eds.), Uncertain Risk s Regulated. Facing the Unk nown in National, EU and International Law, (London and New York: Routledge, 2009), pp.1-17.

27 Fern Wickson \& Brian Wynne, "Ethics of Science for Policy in the Environmental Governance of Biotechnology: MON810 Maize”, 15, Europe, Ethics, Policy \& Environment, (2012), pp. 321 et sqq.; Fern Wickson \& Brian Wynne, "The Anglerfish deception - The light of proposed reform in the regulation of GM crops hides underlying problems in EU science and governance", 13, European Molecular Biology Organization Reports, (2012), pp.100 et sqq.

28 Yann Devos, Pieter Maeseele, Dirk Reheul, Linda van Speybroeck, \& Danny de Waele, "Ethics in the societal Debate on Genetically modified organisms: A (re)quest for sense and sensibility", 21, Journal of Agricultural and Environmental Ethics, 2008, pp. 29 et sq9. 
Interdisciplinary scholarly work (see Everson \& $\operatorname{Vos}^{29}$, Hristova ${ }^{30}$, Zurek ${ }^{31}$, Van Asselt, Versluis \& $\operatorname{Vos}^{32}$ ), as well as legal scholars working on the same topic (in particular see: Weimer ${ }^{33}, \operatorname{Vos}^{34}$ ) have contributed to this research area.

Nevertheless, it is important to keep in mind that we do not aim at pointing out the contrasts of different sciences but rather attempt to complement them in our proposal. In this regard interdisciplinary work seems to be the only solution to move forward. The combination of our educational backgrounds in law, social sciences and political sciences adds to the interdisciplinary nature of this article.

\section{The Former Authorization Procedure and the Importance of Science}

The first deadlock on GMO authorization has its origins in the complex interplay of scientific risk assessors and political risk managers. This section aims at providing a short overview of the authorization process to consequently analyse the first deadlock. Two legislative acts govern the former regulatory framework on the GMO authorization

29 Everson \& Vos, The Scientification of Politics and the Politicisation of Science, supra note 17.

30 Vessela Hristova, "Between Politics and Science. Accommodating National Diversity in GMO Regulation", in Marjolein B.A. Van Asselt, Esther Versluis \& Ellen Vos (eds.), Balancing between trade and risk : Integrating legal and social science perspectives, (London, UK: Routledge, 2013), pp.107 et sqq.

31 Karolina Zurek, "Regulating Food Trade in the Enlarged European Union", in Marjolein B.A. Van Asselt, Esther Versluis, \& Ellen Vos (eds.), Balancing between trade and risk : Integrating legal and social science perspectives, (London, UK: Routledge, 2013), pp. 15 et sqq.; Karolina Zurek, "Indicating Reasons for National GM “Opt-Outs": The Way Forward or a Dead End Street?", 2, European Journal of Risk Regulation, (2011), p. 241 et $s 9 q$.

32 Van Asselt et al., Balancing between Trade and Risk, supra note 20.

33 Maria Weimer, "EU Risk Governance of 'Cloned Food”, in Marjolein B.A. van Asselt, Esther Versluis \& Ellen Vos (eds.), Balancing between trade and risk: Integrating legal and social science perspectives, (London, UK: Routledge, 2013), pp.33 et sqq.

34 Maria Weimer, "What Price Flexibility? - The Recent Commission Proposal to Allow for National "OptOuts" on GMO Cultivation under the Deliberate Release Directive and the Comitology Reform PostLisbon", 4, European Journal of Risk Regulation (2010), pp.345 et sqq, at p. 345. 
procedure in the $\mathrm{EU}^{35}$ While the Directive $2001 / 18 / \mathrm{EC}^{36}$ regulates the deliberate release of GMOs as products or as part of products on the market, Regulation 1829/2003 $3^{37}$ applies to GM food and feed. Before being merchandised, a GMO seed needs to pass a scientific risk assessment of potential effects on human health and the environment under the Directive. ${ }^{38}$ The agency EFSA was established in reaction to the de facto moratorium as an independent and objective risk assessor to provide the EU and its Member States "with the best possible scientific opinions in al cases". ${ }^{39}$

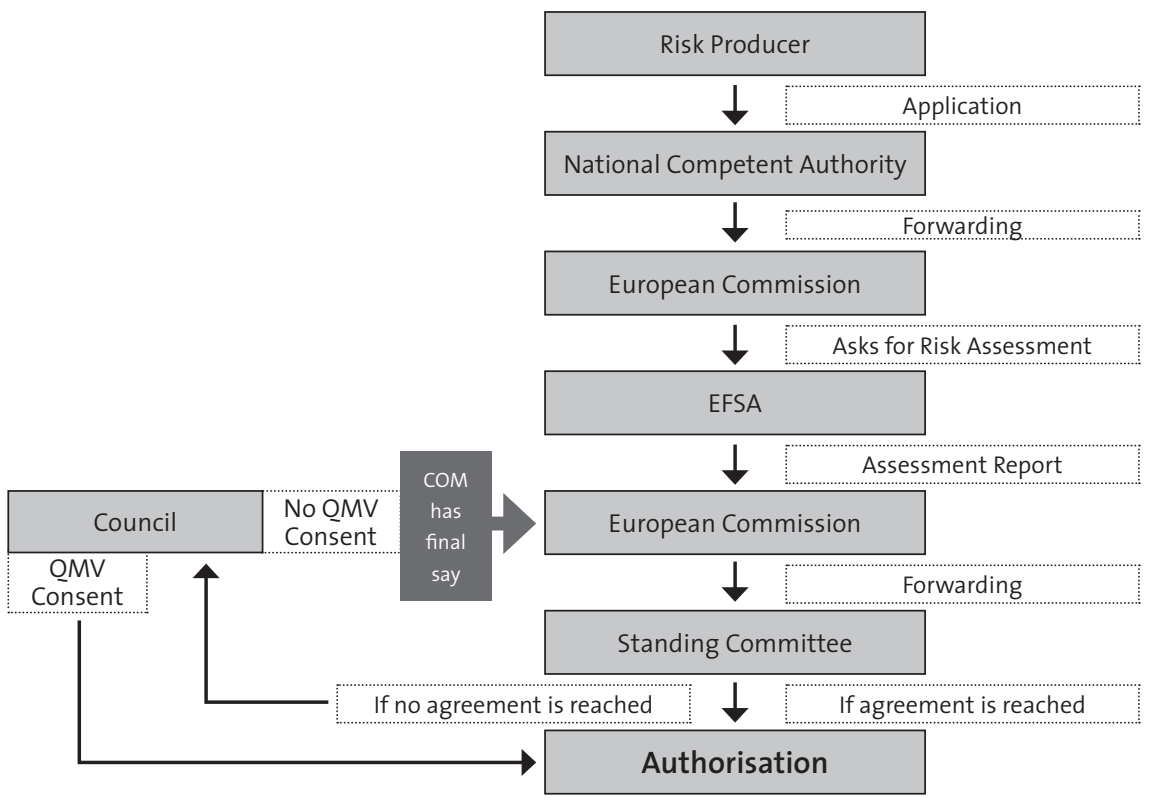

Graph 1 Notification procedure for GMO authorization under Directive 18/2001/EC

35 Since Regulation 182/2011 is in effect, the comitology procedure has changed so that "only the comitology committee composed of representatives of national administrations will be able to approve or reject the draft acting with a qualified majority of its members", see in Weimer, What Price Flexbility?, supra note 34. Therefore, the comitology procedure was reduced to a two stage one. However, as the procedure before has led to the first deadlock, we describe the former one in this section.

36 Directive 2001/18/EC, supra note 3.

37 European Parliament and Council Regulation (EC) No 1829/2003 on genetically modified food and feed, OJ 2003 L 268.

38 Directive 2001/18/EC, supra note, Art. 1.

39 Regulation 178/2002, supra note, Art. 23 (a). 
The placement of a GMO on the internal market must be preceded by the notification procedure laid down in Directive 2001/18/EC and presented in Graph 1. The GM-company needs to notify the national competent authority (the national risk assessor) of the Member State where it first wants to market the product. ${ }^{40}$ The authority assesses the notification and indicates whether the product is scientifically safe for human health and the environment. ${ }^{41}$ EFSA writes its opinion by drawing on national authorities' risk assessments. ${ }^{42}$ After the Commission and the Member States have received EFSA's risk assessment, a standing committee decides on the GMO authorization. ${ }^{43}$ If no Member State objects the placing on the market, the initial risk assessor gives written consent to the GM-company merchandise the product. ${ }^{44}$

In the case that all Member States do not mutually recognize the risk assessment, a qualified majority needs to be found in the Council. The decision maker of last resort is the Commission, usually accepting the authorizations. ${ }^{45} \mathrm{~A}$ Member State can stil ban "the use and/or sale" ${ }^{46}$ of an already authorized GMO by evoking the safeguard clause ${ }^{47}$ of Directive 2001/18/EC. ${ }^{48}$ Coherence of the authorization standards to resort to natural sciences is guaranteed, as this clause requires the submission of new and additional scientific information on potential adverse effects of that GMO on human health and the environment. The Member State must inform the Commission and the other Member States as well as the public. ${ }^{49}$ A decision at EU level must first be taken in the committee again. If no agreement is reached, the draft decision is forwarded to the Council. ${ }^{50}$ In the case that still no consent can be found here either, the Commission can directly request a

40 Directive 2001/18/EC, supra note 3, Art. 13.2.

41 Directive 2001/18/EC, supra note 3, Art. 14.3.

42 Maria Lee, EU Regulation of GMOs. Law and Decision Making for a New Technology, (Cheltenham: Edward Elgar, 2009), at p. 67.

43 Lee, EU Regulations of GMOs, supra note 42, at p. 66.

44 Directive 2001/18/EC, supra note 3, Art. 15.3.

45 "It should be noted that under the regulatory procedure so far all authorisation decisions drafted by the Commission reached the Council stage, and finally were adopted by the Commission by default", Weimer, What Price Flexbility?, supra note 34, at p. 351.

46 Directive 2001/18/EC, supra note 3, Art. 23.1.

47 Directive 2001/18/EC, supra note 3, Art. 23.

48 Before, the safeguard clause was laid down in Directive 90/220/EEC, which was the predecessor of Directive 2001/18/EC.

49 Directive 2001/18/EC, supra note 3, Art. 23.1.

50 Directive 2001/18/EC, supra note 3, Art. 23.1. 
Member State to revoke the ban, as described below. Generally, it is essential to note that the entire authorization procedure is based on the assessment of the outcome of natural sciences studies and the interpretation of this assessment by risk management. Risk regulation thus always resorts to natural sciences as an 'arbiter' between risk assessors, on the one hand, and risk managers, on the other hand.

\subsection{The Authorization Procedure in Practice - the First Deadlock}

As shown above, the authorization procedure resorts to natural science to create reliable and accurate standards. In practice, however, the authorization procedure has developed into a heated debate both at the national and the EU level since national bans on cultivation and imports have been disputed for over a decade. ${ }^{51}$ Austria, for example, continuously voted against GMOs in the Council and persistently evoked the safeguard clause to ban GMO marketing and cultivation..$^{52}$ It was the first Member State to ban MON810 ${ }^{53}$ after Monsanto's application for marketing the GMO in France and the subsequent authorization of cultivation in $1998 .{ }^{54}$ The Austrian risk assessor justified the ban with potential adverse effects on human health and the environment ${ }^{55}$, emphasising scientific uncertainty as the main reason. ${ }^{56}$ In the wake of the Austrian import ban of MON810, five Member States issued a declaration cal ing "for the adoption of a more rigorous and transparent

51 EurActiv, "GMO debate continues to divide EU”, 15 April 2013, available on the Internet at http://www. euractiv.com/climate-environment/gmo-debate-continues-divide-eu-news-219382 (last accessed on 14 June 2013).

52 GMO-free regions 2012, "Austria", no date, available on the Internet at: http://www.gmo-free- regions org/gmo-free-regions/austria.html (last accessed on 6 June 2013).

53 In 1999, Austria evoked the safeguard clause under Directive 90/220/EEC Art. 16, which preceded Directive 2001/18/EC, supra note 52.

54 Bundesgesetzblatt für die Republik Österreich, Teil II: Verordnungen, 1999. 175. Verordnung: Verbot des Inverkehrbringens des genetisch veränderten Maises Zea Mays L., Linie MON 810, in Österreich.

55 Bundesministerium für Gesundheit und Frauen (1999). Gründe für die Entscheidung der Republik Österreich, das Inverkehrbringen der gentechnisch veränderten Maislinie MON810, notifiziert von der Fa. Monsanto Europa SA gemäß der Richtlinie 90-220/EWG und zugelassen von der Französischen Republik am 5. August 1998, zu verbieten. Available on the Internet at http://bmg.gv.et/cms/home/ attachments/2/2/5/CH106o/CMS1212741055132/mon810_begruendung.pdf (last accessed on 14 June 2013), at pp. 2-4.

56 "as long as newly emerging uncertainties in the assessment are not finally resolved, Austria has reason to believe that the cultivation of the product MON810 constitutes a risk for human health and the environment", see BMFG, supra note 55 , at p. 5 .

57 Bundesgesetzblatt für die Republik Österreich, Teil II: Verordnungen, 1999. 175. Verordnung: Verbot des Inverkehrbringens des genetisch veränderten Maises Zea Mays L., Linie MON 810, in Österreich. 
regulatory framework." ${ }^{158}$ The resulting de facto moratorium brought authorization of GM foods for marketing in the EU to a halt ${ }^{59}$ and was only lifted in 2004, after Directive 2001/18/EC and Regulation 1829/2003 were in effect and EFSA ${ }^{60}$ was established. ${ }^{6}$

Austria, however, stayed persistent and forwarded further information to the Commission regarding its national import ban on MON810. EFSA reacted by issuing a new assessment and declared that its risk assessment is still valid as Austria did not provide new scientific insights. Thus, the Commission concluded that Austria must revoke the import ban on MON810. In 2005, the Council, nevertheless, rejected the Commission's proposal to take action against Austria with a qualified majority. Furthermore, it persistently took the stance that scientific uncertainty about the risks of MON810 was still prevalent and that a consideration of whether the national import ban could be justified as a precautionary measure was appropriate. ${ }^{62}$ Although EFSA and the Commission declared the cultivation of MON810 to be safe once more, other Member States joined Austria in evoking the safeguard clause to ban the $\mathrm{GMO}^{63}$. The failure to come to an agreement "can at least partly be explained by the fact that Member States' interests are not reflected fully at the risk assessment stage". ${ }^{64}$ We define this stalemate as the first deadlock as this obvious clash between the Member States' and the Commission's needs hindered the procedure of authorization of GMOs significantly.

58 Joachim Scholderer, "The GM foods debate in Europe: History, regulatory solutions, and consumer response research", 5, Journal of Public Affairs, (2005), pp. 263 et sq9., at p. 267-the Member States were Denmark, France, Greece, Italy and Luxembourg.

59 Scholderer, "The GM foods debate in Europe", supra note 58, at p.267.

6o EFSA was created with the aim to create more accurate and reliable standards for GMO authorization across the EU- see Directive 2001/18/EC supra note 3, Art.4.3 and Regulation 178/2002 supra note 4, Art. 23 (j).

61 Scholderer, "The GM foods debate in Europe”, supra note 58, at p.268.

62 Kommission, Entscheidung der Kommission über das vorübergehende Verbot der Verwendung und des Verkaufs von genetisch verändertem Mais (Zea mays L., Linie MON810) gemäß der Richtlinie 2001/18/EG des Europäischen Parlaments und des Rates in Österreich, K (2008) 1718.

63 GMO-free Europe 2012, "GE cultivation bans in Europe", no date, available on the Internet at: http://www. gmo-free-regions.org/gmo-free-regions/bans.html (last accessed on 4 June 2013); EurActiv, "Bulgaria approve law to ban GMO crops", 5 November 2012, available on the Internet at: http://www.euractiv. com/cap/bulgaria-approves-law-ban-gmo-cr-news-355729 (last accessed on 4 June 2013) - Member States banning GMOs until 2010 were: Austria, France, Greece, Hungary, Germany, Luxembourg and Bulgaria.

64 Jinhee Kim, Christoph Klika, \& Esther Versluis, "Agencies as Risk Managers? Exploring the role of EU agencies in authorization procedures", in Marjolein B.A. van Asselt, Esther Versluis \& Ellen Vos (eds.), Balancing between trade and risk : Integrating legal and social science perspectives, (London, UK: Routledge, 2013), pp. 175 et sqq.; at p.191. 


\section{1.a External and Internal Repercussions of the First Deadlock}

The importance of reforming the authorization procedure became more important as the clash between EFSA and Austria's national competent authority expanded to the international sphere. When the USA, Canada and Argentina argued in the EC Biotech case that the national import bans in the EU were not in line with the WTO rules on free trade, the WTO Panel in charge ${ }^{65}$ stated that the import bans were indeed illegal. The main reason for this ruling was that Austria's risk assessment did not conform to WTO requirements for scientific risk assessments. ${ }^{66}$ In 2007, Austria issued a revised risk assessment in which it defended the banning of gene maize in light of the WTO dispute. The assessment restated the adverse effects argument, but also included economic losses to the organic farming sector as a reason to ban MON810. ${ }^{67}$ This was the first risk assessment that expanded its argumentation to 'non-risk' ${ }^{, 68}$ issues and in particular to socio-economic grounds. ${ }^{69}$

At the EU level, the Council resumed these new grounds in their argumentation. In its statement on the Austrian ban it stresses that risk assessment should take agricultural structural differences as well as regional ecological characteristics into account. ${ }^{70}$ Since the Council failed to agree on the legality of Austria's ban, the Commission directly requested Austria to al ow the cultivation and marketing of MON810 in 2008. This time, the Commission explicitly referred to the ban to import and process MON810 in Austria, but left the issue of cultivation unmentioned. ${ }^{71}$ Austria, however, repealed the ban only

65 Michael Eckerstdorfer, Andreas Heissenberger \& Helmut Gaugitsch, Supplementary Risk Assessment for GM Maize MON810 with regard to the conclusions of the WTO-Panel in the case "EC Biotech" on Austrian safeguard measures for GM Maize, (Wien: Bundesministerium für Gesundheit, Familie und Jugend, Sektion IV, 2007).

World Trade Organisation (2006). European Communities - Measures Affecting the Approval and Marketing of Biotech Products (WT/DS291/R, WT/DS292/R, WT/DS293/R). Reports of the Panel. available on the Internet at: http://www.worldtradelaw.net/reports/wtopanelsfull/ec-biotech(panel)(full).pdf (last accessed on 14 June 2013).

67 Eckerstdorfer, Heissenberger \& Gaugitsch, Assessment for MON810, supra note 65, at pp. 23-25.

68 Brian Wynne, “Elephants in the room where publics encounter 'science'?: A response to Darrin Durant 'Accounting for expertise: Wynne and the autonomy of the lay public'" in 17, Public Understanding of Science, (2008), pp. 21 et sqq.: - Such reasons are called 'non-risk' issue in this context, since they are not primarily about threats to human health or the environment, but comprise a myriad of public issues about new technologies.

69 According to Weimer, the term 'socio-economic' is not clearly defined in this respect, see Weimer, What Price Flexbility?, supra note 34.

70 Entscheidung der Kommission über Verbot von MON810, supra note 62. Entscheidung der Kommission über Verbot von MON810, supra note 62. 
to issue a new one on the import of gene maize..$^{72}$ Austria's revised risk assessment and the subsequent Council statement show a development to expand beyond a traditional risk assessment based on natural sciences. The latter could not do justice to its 'arbiter' role attributed to them in the risk assessment process. Moving to 'non-risk' issues such as socio-economic reasons elucidates that grounds that could not be assessed permeated the GMO controversy. Due to scientific uncertainty, no accurate and reliable answer seemed possible which caused the continuous bargaining between risk assessors and managers at the national and EU level. Thus, this lengthy and complicated negotiations regarding scientific evidence in the risk assessment, blocked the Commission and the Member States in the first deadlock. After showing that science was not able to serve as an 'arbiter', we analyse the problems of sciences in risk assessment and scientific uncertainty in particular.

\section{Science as Solution to the First Deadlock?}

Even though the whole GMO authorization process is based on scientific evidence, it is visible from the section above that the recourse to natural sciences did not provide a solution to the first deadlock. Logically the question arises to what an extent in general science is able to solve the first deadlock? As we have seen, natural sciences examining health and environmental effects of GMOs do not provide clear answers, but instead risk assessors infinitely debate the different outcomes of scientific studies. We argue that there are several reasons why in risk regulation, especially regarding GMOs, science cannot solve the deadlock: First, science in itself is flawed; second, the role of risk assessment in the authorization process is inadequate and places science in a role that it simply cannot fulfil; third, the ambiguous role of science in risk management make it impossible for science to be the solution to the deadlock.

\subsection{The Unreliability of Scientific facts}

Scientific facts "are nothing but answers to questions that could have been asked differently". This quote by the sociologist Beck describes precisely one of the main problems for science in its imposed role of being a neutral arbiter in risk assessments.

72 Bundesgesetzblatt für die Republik Österreich, Teil II: Verordnungen, 2008. 181. Verordnung: Aufhebung des Verbots des Inverkehrbringens des gentechnisch veränderten Maises Zea mays L., Linie MON 810 sowie erneutes Verbot des Inverkehrbringens dieser Maislinie zum Zweck des Anbaus in Österreich. 
Unfortunately, differing research questions are not the only problem of scientific studies. Possibly due to a lack of a common regulatory framework for good practice ${ }^{74}$, each scientific study can be based on different methodologies and research designs. ${ }^{75}$ In the context of GMO assessment this explains why some scientific studies conclude that cultivation is nonproblematic whereas others find potential hazards. We argue that the lacks of a common regulatory framework on EU level is not the only problem, there is arguably also a problem of objectivity: the bioethical scientist Rossi states bluntly that "objectivity in risk assessment would require objectivity at each of the subsidiary evaluative levels, and ..., there are numerous reasons to doubt that such an objective standard can be elaborated at present" ${ }^{76}$ Regarding the important role of science in risk assessment, we claim that its problem of objectivity also holds true for the whole scientific assessment process of GMOs.

Nonetheless, we argue that not only science is sometimes not entirely objective, but moreover it is important to see which values and norms determine the focus of the scientific study, as these might influence the outcome. ${ }^{77}$ Therefore, even decisions entirely based on science are not free of any subjective value, in line with Rossi's argument that to be value free and entirely objective, each stage of the entire process needs to objective. ${ }^{78}$ This is not easily done, especially regarding a hot topic such as GMOs. Taking together these issues with science, it is not astonishing that the outcomes of scientific studies for risk assessment are not always the same and sometimes not even comparable. Conclusions drawn from these studies need to be debated within the scientific and political community, as science seems not to be able to fulfil the role of being the ultimate decision-basis. Moreover, these problems with science as such show that differing outcomes in scientific risk studies do not necessarily establish concrete risk. It might only indicate that the scientific study has addressed the topic with another research question or scientific method. Conclusively, this also shows that science is probably unable to provide an absolute basis for EU-wide policies or as sole basis for risk regulation. Moreover,

74 Fern Wickson \& Brian Wynne, "Ethics of Science for Policy in the Environmental Governance of Biotechnology: MON810 Maize”, 15, Europe, Ethics, Policy \& Environment, (2012), pp. 321 et sq9.

75 Wickson \& Wynne, Ethics of Science for Policy in the Environmental Governance of Biotechnology, supra note, at p. 323.

76 John Rossi, “The Prospects of Objectivity in Risk Assessment”, 46, J Value Inquiry (2012), pp. 237 et sq9. (emphasis added).

77 Fern Wickson \& Brian Wynne, "Ethics of Science for Policy in the Environmental Governance of Biotechnology: MON810 Maize”, 15, Europe, Ethics, Policy \& Environment, (2012), pp. 321 et sq9., at p.328.

78 Susan Carr \& Les Levidow, "Exploring the Links Between Science, Risk, Uncertainty, And Ethics In Regulatory Controversies About Genetically Modified Crops", 2, Journal of Agricultural and Environmental Ethics, (2000), pp.29 et sq9., at p.32; Devos et al., "Ethics in the societal Debate on Genetically modified organisms", supra note 28 , at p.46 
it clarifies how the requirement of new and additional scientific evidence might not be adequate to justify a ban. Nonetheless, the Precautionary Principle states that the risk assessment only has to be taken into account by the risk manager. ${ }^{79}$ This touches upon another reason why science cannot be the solution to the deadlock: as analysed by looking into science's role in risk assessment in the EU's framework on risk regulation.

\subsection{Science's role in risk assessment}

During the authorization process, the potential risks of a GMO are addressed in risk assessments, which are conducted at the national and EU level, by the national authorities and EFSA. ${ }^{80}$ The possibility to argue with numerous studies that differ in their judgements on the potential risk of GMOs for humans and the environment leads to yet another factor, explaining why natural sciences cannot be the solution to the deadlock. In risk regulation in general, and also in the GMO authorization process, the uncertainty paradox as established by Van Asselt and Vos is persistent. ${ }^{81}$ Scientific uncertainty manifests itself when science cannot deliver finite answers. Scientific uncertainty is defined in this article as a situation where "scientific or historic proofs of harmful consequences are lacking, but suspicions cannot be fully refuted either". ${ }^{82}$ The uncertainty paradox is produced by risk assessor, EFSA and risk managers, such as the Commission, when they demand concrete scientific evidence ${ }^{83}$, whereas this is arguably not possible in a situation of scientific uncertainty. $^{84}$

Scientific uncertainty has the potential to lead to "irresponsible attenuation of the risk, sustained controversy, deadlocks, legitimacy problems, unintelligible decision-

79 Commission Communication on the precautionary principle, $\operatorname{COM}(2000) 1$.

80 "it was accepted that scientific expertise should be pluralized in risk assessment in order to render more explicit which value judgments about the acceptability of harm are et play, and to take into account the permanent interplay between risk assessment and risk management. That risk assessments conducted by various European and national expert committees often give different outcomes is illustrative of the fact that various interpretations are given, values and ideals held, institutional cultures detained, and precautionary accounts taken." In Devos et al., "Ethics in the societal Debate on Genetically modified organisms", supra note 28 , at p.46.

81 Marjolein B.A. Van Asselt \& Ellen Vos, "The Precautionary Principle and the Uncertainty Paradox", 9, Journal of Risk Research (2006), pp.313 et sq9.

82 Marjolein B.A. Van Asselt \& Ellen Vos, "Wrestling with uncertain risks: EU regulation of GMOs and the uncertainty paradox", 11, Journal of Risk Research, (2008), pp.281 et sqq.

83 Anne-May Janssen \& Marjolein B.A. van Asselt, "The Precautionary Principle in Court - An Analysis of PostPfizer Case Law", in Marjolein B.A. van Asselt, Esther Versluis \& Ellen Vos (eds.), Balancing between trade and risk : Integrating legal and social science perspectives, (London, UK: Routledge, 2013), pp.197 et sqq., at p.197.

84 Van Asselt \& Vos, Wrestling with uncertain risks, supra note 82. 
making, trade conflicts, border conflicts [and] expensive re-bound measures". ${ }^{85}$ Most of these outcomes can be seen in the section describing the first deadlock. In the case of GMOs, risk assessors expect a clear statement by scientists about the potential harmful effects of the product in question. Moreover, under the regulatory framework of Directive $18 / 2001 / E C$, only new and additional scientific evidence justifies a ban. However, as the example of Austria above illustrates, this scientific evidence brought forward is always rejected by EFSA. Therefore, we argue that not only flaws within science but also scientific uncertainty make it impossible for science to solve the first deadlock. Alas, even another tension exists regarding science, risk management and the role of science.

\subsection{Science's role in Risk Management}

Although risk assessment is formally separated from risk management, the scientific risk assessment implicitly guides the risk manager in its decision. ${ }^{86}$ In line with our argumentation and according to Jasanoff, a scholar in the field of science and technology the legal framework should appoint risk assessment the role of "inject[ing] much needed competence and critical intel igence into a system otherwise al too vulnerable to the demands of politics. ${ }^{87}$ As the risk manager, the Commission has to ensure that all differing outcomes between national and EU-level assessments and the opinions of different stakeholders are accommodated in the risk measure. Moreover, GMOs are a highly debated topic: although scientists do not yet agree which risks and benefits GMOs entail, the two-thirds of European public has a negative attitude towards $\mathrm{GMOs}^{88}$ With reference to these miscellaneous stakeholders, another reason of science's inability to solve the deadlock becomes visible: the perception of risk differs between the public and scientists. While "experts describe risk on grounds of strictly scientifically determined standards", emphasize non-scientific reasons for their cautious stance. ${ }^{90}$ Scientists attempt to quantify

85 Marjolein B.A. Van Asselt \& Ortwin Renn, “Risk Governance”, 14, Journal of Risk Research, pp.431 et sq9., at p.438.

86 Hristova, V. (2013), Accommodating National Diversity in GMO Regulation. In Marjolein B.A. van Asselt, Esther Versluis \& Ellen Vos (eds.), Balancing between trade and risk : Integrating legal and social science perspectives, (London, UK: Routledge, 2013), at p.110.

87 Sheila Jasanoff, The fifth branch: Science advisors as policymak ers, (Cambridge, MA: Harvard University Press, 1990)

88 Special Eurobarometer 341, supra note 14; Devos et al., "Ethics in the societal Debate on Genetically modified organisms", supra note 28 , at p.30.

89 Devos et al., "Ethics in the societal Debate on Genetically modified organisms", supra note 28, at p.30.

90 for reference see: Siegrist, 2000; Marris, 2001; Lassen et al., 2002; Shaw, 2002; Verhoog et al., 2003; Cook et al., 2004; Frewer et al., 2004; Deckers, 2005; Madsen and Sand фe, 2005; Lassen and Jamison, 2006 in Devos et al., "Ethics in the societal Debate on Genetically modified organisms", supra note 28, at p.30. 
risk, whereas policy makers often hold qualitative assessments of a product's risk. Such an assessment regards GMOs as a risk to cultural values or socio-economic reasons such as traditional farming, native identity, or ethical implications of gene modification. ${ }^{91}$ Thus, the risk manager does not only face the problems of science, but also needs to accommodate this division between scientists and public.

Applied to the beforehand-discussed deadlock of GMO authorisation, we argue that stakeholders with strong opinions regarding GMOs (e.g. MS, EFSA, Monsanto) possibly base their arguments on different scientific studies that seem to be tailored to support each stakeholder's particular interest..$^{92}$ In other words, Jasanoff holds it: "facts and values frequently merge when we deal with issues of high uncertainty". Even though she argues this in the general context of framing scientific uncertainty, we argue that this also holds true in the debates among stakeholders. According to Knudsen, a biology professor, "politics and science become so intertwined that it can be impossible to separate the scientific questions from the political questions". ${ }^{44}$ Conclusively, science might push the deadlock even further when differing outcomes of scientific studies or the insufficiency of providing clear answers is (mis)used by politics.

Consequently, science cannot - and according to us should not [solely] - be used as the ultimate basis for risk regulation in the GMO authorization process. There are too many flaws, uncertainties and tensions attached to it, making it incapable to accommodate all stakeholders.

\section{The Second Deadlock: Disagreement on the Proposal}

Besides scientific uncertainty with regards to risks and benefits of GMOs, another key element defining the first deadlock on GMO authorization in the EU becomes evident by close analysis of the exact issues at stake. Austria's risk assessment report from 2007,

91 Merkur Online, “Bayern bremst grüne Gentechnik”, 9.August 2010, available on the Internet at: http:// www.merkur-online.de/aktuelles/politik/bayern-bremst-gruene-gentechnik-mm-871416.html, (last accessed on 14 June 2013); Christian Schwägerl, "Gentechnik: Hier geht es um den Heimatbegriff”, 17 October 2010, available on the Internet at http://www.spiegel.de/politik/deutschland/gentechnik-hiergeht-es-um-den- heimatbegriff-a-723550.html (last accessed on 5 June 2013).

92 As was seen in France and Germany - Shane H. Morris \& Charles Spillane, "EU GMO Crop Regulation: A Road to Resolution or a Regulatory Roundabout?", 4, European Journal of Risk Regulation, pp.359 et sqq., at p.363/364.

93 Sheila Jasanoff, “Bridging the Two Cultures of Risk Analysis”, 13, Risk Analysis (1993), at p.123.

94 Guy R. Knudsen, "Where's the Beef? How Science Informs GMO Regulation And Litigation", Idaho Law Review 48, pp. 225-250, at p.230. 
first, lists potential adverse effects of MON810 on human health and the environment. ${ }^{95}$ Secondly, however, the report justifies Austria's ban by stating potential adverse effects of MON810 cultivation with reference on Austria's organic agricultural economy. ${ }^{96}$ The incorporation of the socio-economic consideration of avoiding GMO presence in other products suggests that socio-economic grounds play a role next to health and environmental concerns in defining a Member State's GMO policy.

Moreover, also in the justifications for the German bans, we identified socioeconomic as well as cultural and ethical considerations on GMO policy. Germany has an organic farming sector proportionately smal er than Austria's. ${ }^{97}$ Nevertheless, in 2009, Germany has been the latest Member State to join the ones banning MON810 since the de facto moratorium had been ended. ${ }^{98}$ Interestingly, the German competent authority justified evoking the safeguard clause with new and additional scientific information on adverse environmental effects of MON810 cultivation. Consequently, the ministry of food, agriculture and consumer protection ordered the competent authority to issue a ban, ${ }^{99}$ even though the authority's scientific panel disagreed, stating that there was no scientific evidence for environmental risks of MON810. ${ }^{100}$

This case of Germany shows how the formal distinction between scientific risk assessment and political risk management becomes questionable, when the competent authority disagreed with its own scientific panel. In an interview in 2010, the Bavarian state minister for environment and public health argued that opposition against GMOs was a cultural issue. GMO cultivation would harm regional agricultural structure and contradict local identity. Regional organic farming could not coexist with GMO cultivation. He concluded that GMO cultivation would touch on ethical considerations. ${ }^{101}$

95 Bundesministerium Für Gesundheit, Familie und Jugend, supra note 65, pp.14-22

96 Bundesministerium Für Gesundheit, Familie und Jugend, supra note 65, at p.25.

97 Bundesministerium Für Gesundheit, Familie und Jugend, supra note 65, at p.142.

98 GMO-free Europe 2012, "GE cultivation bans in Europe", no date, available on the Internet at: http:// www.gmo-free-regions.org/gmo-free-regions/bans.html (last accessed on 4 June 2013);

99 Bundesministerium für Ernährung, Landwirtschaft und Verbraucherschutz, (2009). Press release no. 063 from 14.04.2009: Aigner prohibits cultivation of MON810. Available on the Internet at: http://www. bmelv.de/SharedDocs/Pressemitteilungen/EN/063-MON810.html (last accessed on 14 June 2013).

100 Bundesamt für Verbraucherschutz und Lebensmittelsicherheit Abteilung Gentechnik (2009). Bescheid Aktenzeichen 6788-02-13 (C/F/95/12-02). Available on the Internet at http://www.bvl.bund.de/ SharedDocs/Downloads/o6_Gentechnik/ZKBS/o1_Allgemeine_Stellungnahmen_deutsch/o4_Pflanzen/ MON810_Neubewertung_2009.pdf?_blob=publicationFile\&v=3 (last accessed on 14 June 2013).

101 Christian Schwägerl, “Gentechnik: Hier geht es um den Heimatbegriff”, 17 October 2010, available on the Internet at http://www.spiegel.de/politik/deutschland/gentechnik-hier-geht-es-um-den-heimatbegriff-a723550.html (last accessed on 5 June 2013). 
Together, the examples of Austria and Germany give a broader picture of possible grounds on which opposition to GMOs can be founded - grounds inaccessible for the natural sciences, which are central to EFSA's risk assessment, as il ustrated above. Underlying reasons, which were not assessed drove Member States to reject GMOs on their territory. Regarding the two cases of Austria and Germany, the 'arbiter' role of science is made yet again impossible by a risk assessment approach, which does not take into account scientific uncertainty and excludes 'non-scientific' grounds, such as socioeconomic, cultural and ethical reasons. These grounds are also 'non-risk' issues, since they do not deal with potential threats to human health or the environment. As this section shows, the applications of the safeguard clause were not, or were not primarily about risk, thus, GMOs do not touch primarily on scientific questions. Thus, it is wrong "to cal public issues about new technologies which involve risk but which also involve many other issues, 'risk issues',"102 In the current regulatory framework, these reasons are legally insufficient to justify a ban, although they play an important role in the political decisionmaking on GMOs.

Therefore, the proposed Amendment to Directive 2001/18/EC is examined to illustrate the Commission's attempt to resolve the above-described deadlock on GMO authorization. As we have shown with the examples of Austria and Germany, Member States had nonscientific concerns about GMOs, which the new proposal aims to address through the introduction of non-scientific grounds that may be invoked by Member States to justify bans on cultivation of GMOs. After a brief introduction of the proposed amendment, the issues that arose concerning the amendment are discussed.

\subsection{The Proposal: A Solution to the Deadlock?}

In order to resolve the first deadlock several Member States, regardless of pro- or anti-GMO stances, urged the Commission to propose a reform of the GMO regulatory framework. ${ }^{103}$ As a result, the Commission issued an amendment to Article 26 Directive 2001/18/EC. The proposal for a new Article $26 \mathrm{~b}$ allows the possibility for the Member States to restrict or prohibit the cultivation of GMOs in their territory on grounds other than health and environment.

102 Brian Wynne, "Elephants in the room where publics encounter 'science'?: A response to Darrin Durant 'Accounting for expertise: Wynne and the autonomy of the lay public"' in 17, Public Understanding of Science, (2008), pp. 21 et sqq, at p.23.

103 The request was made by the Austrian and Dutch delegations supported by Bulgaria, Ireland, Greece, Cyprus, Latvia, Lithuania, Luxembourg, Hungary, Malta, Poland and Slovenia. See for more details: Council Note on the Subject of Genetically Modified Organisms - A Way Forward - Information from the Austrian delegation, 11226/2/o9. 
'Article 26b Cultivation

Member States may adopt measures restricting or prohibiting the cultivation of all or particular GMOs authorised in accordance with Part $\mathrm{C}$ of this Directive or Regulation (EC) No 1829/2003, and consisting of genetically modified varieties placed on the market in accordance with relevant EU legislation on the marketing of seed and plant propagating material, in all or part of their territory, provided that:

(a) those measures are based on grounds other than those related to the assessment of the adverse effect on health and environment which might arise from the deliberate release or the placing on the market of GMOs;

and,

(b) that they are in conformity with the Treaties.

By way of derogation to Directive 98/34/EC, Member States that intend to adopt reasoned measures under this Article shall communicate them to the other Member States and to the Commission, one month prior to their adoption for information purposes. ${ }^{104}$

According to the Commission, the aim of the proposal is to address specific local or national aspects raised by the cultivation of GMOs by granting Member States an adequate degree of flexibility to decide on GMO cultivation after they have been authorized on EU level. ${ }^{105}$ By making it possible for Member States to invoke grounds that are not related to health or environment as justifications for the limitation of GMO cultivation the proposal aims directly at unlocking the decision making deadlock. This is the case as the proposal attempts to advance the reliability of the decisions on GMO authorization for the

104 Commission Proposal for a Regulation of the European Parliament and of the Council Amending Directive 2001/18/ EC as Regards the Possibility for the Member States to Restrict or Prohibit the Cultivation of GMOs in Their Territory, C(2010) 380 final, C(2010) 4822 final, et Art. 1.

105 Commission Proposal for a Regulation of the European Parliament and of the Council Amending Directive 2001/18/EC, supra note 8, at pp.3-6. 
stakeholders involved by reducing the likelihood of the invocation of the safeguard clause by Member States. However, since 2011 the proposal has been discussed in the Council by four presidencies ${ }^{106}$ and so far three revised compromise proposals have failed to reach a qualified majority on the issue. ${ }^{107}$ In addition to the political ordeal of the proposal's many draft amendments, the Commission proposal to amend Directive 2001/18/EC ${ }^{108}$ raised several legal concerns in its wake. One of the concerns raised by a blocking minority of Member States is the possible clash of such cultivation bans on socio-economic grounds ${ }^{109}$ with WTO and EU law.

Through the creation of the possibility to legally ban GMO cultivation on socioeconomic grounds the proposal could provide - at least to a certain extent - a solution to the above-discussed first deadlock concerning the reliance on scientific justifications for the limitation of GMOs by certain Member States. However, due to the Member State opposition in the Council, a second deadlock has been created concerning this potential solution of the first deadlock. While the permission of non- scientific grounds appears to be an ideal solution, especially in light of the above-discussed issues of Member States concerning GMO cultivation, the question arises whether it is indeed legally feasible.

106 These four presidencies were the Belgian, Hungarian, Polish and Danish presidencies.

107 The Hungarian, Polish and Danish presidencies each have created a new revised compromise version of the proposal, all of which in turn have failed to reach the qualified majority needed. See: For the Hungarian Presidency revised compromise proposal: Council of the European Union Proposal for a Regulation of the European Parliament and of the Council amending Directive 2001/18/EC as Regards the Possibility for the Member States to Restrict or Prohibit the Cultivation of GMOs in their Territory - Preparation for the Informal Trialogue. 20010/0208 (COD) 10532/11. Polish presidency: Council of the European Union Proposal for a Regulation of the European Parliament and of the Council Amending Directive 2001/18/EC as Regards the Possibility for the Member States to Restrict or Prohibit the Cultivation of GMOs in Their Territory - State of play. 2010/0208 (COD), 17634/11. Danish presidency: Council of the European Union Proposal for a Regulation of the European Parliament and of the Council Amending Directive 2001/18/ EC as Regards the Possibility for the Member States to Restrict or Prohibit the Cultivation of GMOs in their Territory - Revised Compromise Proposal in View of a Council Political Agreement (First Reading). 2010/0208 (COD) 7153/12.

108 Commission Proposal for a Regulation of the European Parliament and of the Council Amending Directive 2001/18/EC, supra note 8.

109 The term socio-economic grounds still lacks clarity, see: Commission Report to the European Parliament and the Council on Socio-Economic Implications of GMO Cultivation on the Basis of Member States Contributions, as Requested by the Conclusions of the Environment Council of December 2008. Brussels, $\operatorname{COM}(2011)$ final.

110 This blocking minority consists of DE, FR, UK, and BE. See: Council of the European Union "I/A" Item Note on the Proposal for a Regulation of the European Parliament and of the Council amending Directive 2001/18/EC as Regards the Possibility for the Member States to Restrict or Prohibit the Cultivation of GMOs in Their Territory, $108883 / 1 / 12$, at p. 5 . 
In order to better understand whether the proposal could provide a solution for the untangling of the second deadlock, the legal issues that have appeared problematic with regard to the Commission's proposal are important to examine. These legal problems formed one of the main concerns of the Member States in the Council, and were thus leading to the deadlock as one of the heated subjects of discussion. Thus, this chapter aims to answer how far this proposal is legally viable. The compatibility of the proposal with EU internal market rules, and specifically the list of grounds invocable by Member States is first discussed. Furthermore, possible conflicts with WTO regulations concerning the proposal are also examined.

\subsection{EU Internal Market Compatibility}

In order to determine the proposal's compatibility with EU law, the effect of the restriction or prohibition of the cultivation of GMOs on the internal market needs to be taken into consideration. The issue of such compatibility was first raised by the ad hoc working party established by COREPER to consider the Commission's original version of the proposal." ${ }^{112}$ Later on the question was also one of the main factors discussed both in the EP as well as in the Council, with special regard to the need for a clear list of grounds that may be invoked.

While the purchase of GM seeds would thus not be prohibited, in practice cultivation limitations would have an indirect effect on the free circulation of GM seeds. ${ }^{113}$ This way, the free circulation of goods could be hindered (Article 34 Treaty on the Functioning of the European Union (TFEU)). Hence, Member States attempting to restrict the cultivation of GMOs must ensure that the measure is justified by one of the exceptions of Article 36 TFEU - most likely 'on grounds of public morality, public policy or public security' -, or any other compulsory requirements based on the case law of the Court of Justice of the European Union (CJEU) or secondary legislation. The reasons relating to the public interest which Member States could invoke to restrict or prohibit GM cultivation thus needs to be clarified. However, according to the court's judgement in Decker the free movement

111 Council Press Release of the $3075^{\text {th }}$ Council Meeting, $7689 / 11$, at p. 8.

112 Commission Staff Working Document on the Considerations on Legal Issues on GMO cultivation raised in the opinion of the Legal Service of the Council of the European Union of 5 November 2010, SEC(2010) 1454 final, at p. 3.

113 Commission Staff Working Document on the Complementary Considerations on Legal Issues on GMO Cultivation Raised in the Opinions of the Legal Service of the Council of the European Union of 5 November 2010 and on the Legal Service of the European Parliament on 17 November 2010 (Indicative List of Grounds for Member States to Restrict or Prohibit GMO Cultivation), SEC (2011) 184 final, at p. 2. 
of goods may not be restricted by 'purely economic' goals. ${ }^{114}$ The grounds also must be in accordance with the general common market exemptions criteria of being justified, proportionate and non-discriminatory.

According to the proposed Article 26b, the national measures must be based on grounds other than environmental and health risk assessments, thus formulating a negative definition of admissibility. ${ }^{115}$ The phrasing of the proposal suggests that the socio-economic aspect of GMO cultivation is referred to, which - due to its broad meaning lacking specific examples - has been criticized as lacking clarity. This varied list of grounds thus created through the negative formulation of the Commission appears to indicate that by creating wide-ranging possibilities for Member States to deviate from the general EU authorization of cultivation, the proposal attempts to reduce the scope of harmonization of the legal framework on GMO cultivation. ${ }^{116}$ Due to the ambiguity of the negative formulation of grounds found in the original proposal, the Commission Services released a non- exhaustive list of possible grounds that could be invoked to limit the cultivation of GMOs. ${ }^{17}$ The seven grounds listed by the Commission Services were the following: "public morals, public order, avoiding GMO presence in other products, social policy objectives, town and country planning or land use, cultural policy and general environmental policy objectives, other than assessment of the adverse effects of GMOs on the environment." ${ }^{118}$ As six grounds out of the seven indicated in the list of the Commission are socio-economic in their nature, the division between scientific assessment, that is environmental and health concerns, and socio-economic evaluation is demonstrated.

Consequently, as emphasis is placed on socio-economic grounds, it is helpful to examine the Member States assessment of the socio-economic impact of GMOs. The Commission report on the socio-economic implications of GMO cultivation ${ }^{119}$ found - on the basis of Member States' contributions - that the perception of the definition of socioeconomic dimension of GMO cultivation deviates greatly between the Member States and

114 Case C-120/95, Decker 1998 ECR 1831, at para. 39.

115 Weimer, What Price Flexbility?, supra note 34, at p.348.

116 Weimer, What Price Flexbility?, supra note 34, at p.348.

117 Commission Staff Working Document on the Complementary Considerations on Legal Issues on GMO Cultivation supra note 113 .

118 Commission Staff Working Document on the Complementary Considerations on Legal Issues on GMO Cultivation supra note 113, at p. 2.

119 Report from the Commission to the European Parliament and the Council on Socio-Economic Implications of GMO Cultivation on the Basis of Member States Contributions, as Requested by the Conclusions of the Environment Council of December 2008. Brussels, $\operatorname{COM}(2011)$ final. 
the various stakeholders. The main focus of the submissions of the Member States entails the co-existence of GM and organic methods starting with the cultivation of seeds all the way to the end products reaching the shelves, although the greatest focus of the study was directed towards initial part of the process concerning cultivation. Views concerning other socio- economic impacts on the seed-to-shelves chain and the greater society generally lacked proper scientific and statistical documentation. ${ }^{120}$ The general conclusion of the report is that the analysis of socio- economic impacts of GMO cultivation in Europe lacks the necessary objectivity. ${ }^{121}$ While there is available analysis of the economic impacts at the farmer level, the discussion of social impacts is lacking. ${ }^{122}$

The Danish presidency in the Council aimed to solve the deadlock on the proposal by creating their own revised version. Since a blocking minority of Member States had until then prevented previous versions from passing, the Danish version tried to accommodate all interested parties by including a list of grounds Member States could use. ${ }^{123}$ This is an advancement towards legal certainty when compared with the original version of the proposal by the Commission, which only contained a negative definition of the invocable grounds. In addition to grounds related to environmental policy objectives not conflicting with the evaluation of risks to health and the environment, under the Danish proposal Member States could also use 'grounds concerning socio-economic impacts that might arise from the cultivation of a $\mathrm{GMO}^{\prime 2}{ }^{124}$ It is further elaborated that the environmental grounds may only be relied on if they 'do not conflict with the assessment of risks to health and the environment which are assessed in the context of the authorization procedures'. ${ }^{125}$ This however does raise the issue of the justification of a ban by general

120 Report from the Commission to the European Parliament and the Council on Socio-Economic Implications of GMO Cultivation on the Basis of Member States Contributions, supra note 119; at p. 3-5.

121 Report from the Commission to the European Parliament and the Council on Socio-Economic Implications of GMO Cultivation on the Basis of Member States Contributions, supra note 119; at p. 7 .

122 Report from the Commission to the European Parliament and the Council on Socio-Economic Implications of GMO Cultivation on the Basis of Member States Contributions, supra note 119; at p. 6.

123 EurActiv.com with Reuters, "Danes Seek Compromise on GM Crops", 3 February 2012, available on the internet at http://www.euractiv.com/cap/danes-seek-compromise-gm-crops-news-510562 (last accessed on 13 June 2013).

124 Council of the European Union Proposal for a Regulation of the European Parliament and of the Council Amending Directive 2001/18/EC as Regards the Possibility for the Member States to Restrict or Prohibit the Cultivation of GMOs in their territory - Revised compromise proposal in view of a Council Political Agreement (first reading). Interinstitutional File: 2010/O208 (COD) 7153/12, at p. 7 para. 12.

125 Council of the European Union Proposal for a Regulation for the European Parliament and of the Council Amending Directive 2001/18/EC as Regards the Possibility for the Member States to Restrict or Prohibit the Cultivation of GMOs in their territory, supra note 124, at p. 7, para. 11. 
environment policy objectives in a situation where the GMOs have already been assessed for their potential environmental risk. ${ }^{126}$ Most likely, the environmental policy objectives may rather be relied on only for cases of limitation or prohibition of cultivation in only restricted geographical areas.

Concerning the socio-economic grounds, the four specifically mentioned by the Danish proposal are related to the difficulties of implementing coexistence measures due to geographic conditions, avoidance of GMO presence in other products, the need to protect agricultural production diversity, or the need to ensure seed and plant propagating material purity. All of these are rather concerned with more specific issues - when compared to the ones in the Commission's indicative list of grounds -, which could be evidenced by statistical and scientific data. However, the grounds of the Danish proposal also only appear to be an indicative list, as there is no suggestion of it being exhaustive.

The Danish proposal is most likely not going to be the last version of the proposal, as it failed to reach qualified majority in the Council. ${ }^{127}$ Thus, there still is room for further improvement of the grounds. Including a list of grounds in the proposed Article 26(b) and make such a list binding could help raise legal certainty ${ }^{128}$ while providing guidance to the Member States. ${ }^{129}$ The improvement of the Danish proposal when compared with the original proposal from 2010, illustrates that while the issue of grounds has not been completely resolved, the creation of an indicative list and its subsequent incorporation to a certain extent into the latest proposal version indicates that the matter is being dealt with.

\subsection{Compatibility with WTO Regulation}

Since the European Union is a player of the global trade community, it must abide by international trade rules. Therefore, the compatibility of the proposal with WTO rules is the second main legal issue that has been frequently questioned by the Council Legal

126 Karolina Zurek, “Indicating Reasons for National GM “Opt-Outs": The Way Forward or a Dead End Street?", 2 European Journal of Risk Regulation (2011), pp. 241 et sqq., at p. 243.

127 The reason for the failure of the Danish proposal was explained in the Press Release of the $3152^{\text {nd }}$ Enviroment Council Meeting, 7478/12, at p. 11: 'Although a large number of member states could accept the Presidency proposal, it was not yet possible to reach agreement in the Council. Some member states still had concerns regarding:

- the legal compatibility of some provisions in the proposal with WTO and EU internal market rules;

- how to avoid possible overlaps and/or inconsistencies between the mandatory risk assessment at EU level and national environmental measures;

- the implementation of the Environment Council conclusions adopted on 4 December 2008.'

128 Legal certainty means that the law will have clarity, stability and intelligibility in the sense that those concerned, in our case the Member States will be able to predict with relative certainty the legal consequences of the invoked bans. See: Elina Paulino, "Beyond Predicta

129 Commission Proposal for a Regulation of the European Parliament and of the Council Amending Directive 2001/18/EC, supra note 8 , at pp. 3-6. 
Service $^{130}$ as well as Member States in the Council during the debate surrounding its adoption. ${ }^{131}$ The proposal itself appears to be compatible with WTO rules. However, problems may arise concerning future measures that would be adopted under the future Article 26(b). The WTO Agreement on the Application of Sanitary Phytosanitary Measures (SPS) and the Agreement on Technical Barriers to Trade (TBT) are not likely to be an issue for any national measures, as the proposed Article $26 \mathrm{~b}$ explicitly forbids the invocation of health grounds for the limitation of GMO cultivation by Member States. ${ }^{132}$

Rather the General Agreement on Tariffs and Trade (GATT) compatibility of the proposal could lead to possible difficulties. The recent cases of EC-Hormones ${ }^{133}$ and EC-Biotech ${ }^{134}$ in particular, illustrate the failure of the EU to successfully defend its protective stance towards new food technologies in front of the WTO dispute settlement body. Most of the grounds of the indicative list discussed above are unlikely to provide sufficient justification under current WTO rules. The compatibility of a newly adopted national measure limiting or prohibiting cultivation of GMOs would depend on the nature of the measure and the circumstances of the adoption. ${ }^{135}$

The position of the EU before the WTO is dual in its nature, as it both represents the entire Union, as well as the individual Member States. If a Member State would choose to opt out under the new Article $26 \mathrm{~b}$, this would lead to a shift of responsibility from the Commission to the Member States. ${ }^{136}$

Therefore, to conclude both in the context of EU as well as WTO law the compatibility of the proposal is largely dependent on the grounds that Member States could invoke. The proposal itself is legally compatible under EU internal market rules as long as proper justifications are provided for any future bans invoked under the proposal. However, in

130 Commission Staff Working Document on the Considerations on Legal Issues on GMO cultivation raised in the opinion of the Legal Service of the Council of the European Union of 5 November 2010, SEC(2010) 1454 final, at para. 48-65.

131 Council Press Release of the $3075^{\text {th }}$ Council meeting, $7689 / 11$, at p. 8.

132 Commission Staff Working Document - Considerations on Legal Issues, supra note 130, at para. 48 \& 54 .

133 EC - Hormones (US) (Article 22.6 - EC) - Decision by the Arbitrators, European Communities -Measures Concerning Meat and Meat Products (Hormones), Original Complaint by the United States -Recourse to Arbitration by the European Communities under Article22.6 of the DSU, WT/DS26/ARB, 12 July 1999 , DSR1999:III, 1105.

134 EC - Approval and Mark eting of Biotech Products: Panel Reports, European Communities - Measures Affecting the Approval and Marketing of Biotech Products, WT/DS291/R/WT/DS292/R/WT/DS293/R, Et.1 to Et.9, and Corr.1, adopted 21November 2006, DSR2006:III-VIII, 847.

135 Commission Staff Working Document - Considerations on Legal Issues, supra note 130,at para. 64 .

136 Weimer, What Price Flexibility, supra note 33, at p. 348. 
order to ensure that legal certainty is provided the current proposal would need to be altered. The following section discusses our suggestions in order to achieve such greater clarity of the law.

\section{Unlocking the Deadlocks?}

While the Commission proposal itself has not yet provided a perfect solution to the deadlock, already the fact that a version of the proposal by the Danish presidency contained at least in its preamble an indicative list of grounds reflects on the development of the last couple of years concerning the deadlock. This is perhaps best illustrated by an example of the Commission decision on the Polish draft act on GMOs in $2008 .^{1.37}$ Poland at that time attempted to rely on six out of the seven socio-economic grounds of the indicative list of reasons relating to the public interest which could be invoked. ${ }^{138}$ The Commission, however, in its decision did not even discuss the invocation of these grounds, instead only emphasizing the lack of new scientific information. ${ }^{139}$ This is in stark contrast to the 2011 Commission document on the Indicative List of Grounds to Restrict or Prohibit GMO Cultivation, where the Commission mentions exactly those grounds that it ignored in the case of Poland three years earlier. ${ }^{140}$

Our own suggestion for providing a potential solution to the deadlock requires the inclusion of a non-exhaustive list of grounds in the proposed Art. 26b. The clarification of these grounds is to be supported by the creation of a committee to assess the justifications.

137 Karolina Zurek, “Indicating Reasons for National GM “Opt-Outs”: The Way Forward or a Dead End Street?", 2 European Journal of Risk Regulation (2011), pp. 241 et sqq.

138 In particular: '(1) the need to fulfil the expectations of Polish society; (2) richness of biodiversity and the need to prevent serious disturbances to the functioning of the environment; (3) the fragmented structure of Polish agriculture; (4) specific agricultural production profile with domination of conventional traditional and organic farming; (5) following from the two previous characteristics - the impossibility of elimination of a risk of cross- contamination and preventing of potential damage that could be caused as a result of crossover of transgenes into conventional crops; (6) the need to limit the cultivation of GM plants to areas that do not contain elements of value for nature conservation, and whose agrarian structure enables the safe cultivation of transgenic plants without damaging the nature and the operations of other farmers.' See in: Karolina Zurek, "Indicating Reasons for National GM "Opt-Outs": The Way Forward or a Dead End Street?", 2 European Journal of Risk Regulation (2011), pp. 241 et sqq., at p. 244.

139 Case C-165/08, Commission of the European Communities v Republic of Poland [2009] ECR I-6843.

140 Council of the European Union Cover Note on the Complementary Considerations on Legal Issues on GMO Cultivation Raised in the Opinions of the Legal Service of the Council of the European Union of 5 November 2010 and of the Legal Service of the European Parliament of 17 November 2010, 16826/10, at pp. 2-3. 
Furthermore, two possible examples for the assessment procedure to be performed by the committee are discussed.

\subsection{Inclusion of Indicative List of Grounds in Art. 26b}

In order to ensure legal certainty and provide some guidance to Member States for invoking a ban on societal grounds in this article we argue that an indicative list of grounds should be included in the proposed Art. 26b of Directive 2001/18/EC itself.

The indicative list proposed by the Commission is as follows:

- 'Public morals (including religious, philosophical and ethical concerns);

- Public order;

- Avoiding GMO presence in other products, i.e. contributing to:

- Preservation of organic and conventional farming systems;

- Avoiding the presence of GMOs in other products such as particular food products under GM-free schemes;

- Social policy objectives, e.g.:

- Keeping certain type of rural development in given areas to maintain current levels of occupation (such as specific policy for mountain regions);

- Town and country planning/land use;

- Cultural policy, e.g.:

- preservation of societal traditions in terms of traditional farming methods;

- preservation of cultural heritage linked to territorial production processes with particular characteristics;

- General environmental policy objectives, other than assessment of the adverse effects of GMOs on environment; e.g.:

- Maintenance of certain type of natural and landscape features;

- Maintenance of certain habitats and ecosystems (i.e. preservation of the conservation status quo);

- Maintenance of specific ecosystem functions and services (e.g. preservation of nature-oriented regions of particular natural and recreational value to citizens). ${ }^{141}$

141 Council of the European Union Cover Note on the Complementary Considerations on Legal Issues on GMO Cultivation Raised in the Opinions of the Legal Service of the Council of the European Union of 5 November 2010 and of the Legal Service of the European Parliament of 17 November 2010, 16826/10, at pp. 2-3. 
While arguably an exhaustive list of grounds would provide greater legal certainty than an indicative list, as it is impossible to foresee all possible scenarios in which Member States would invoke Art. $26 \mathrm{~b}$ in the future, a certain level of flexibility concerning the invocable justifications should be enabled. However, only providing an indicative list, while definitely being an improvement, does not provide sufficient clarity and legal certainty concerning the nature of justifications that Member States could possibly rely on. The regulatory framework should provide proper guidance for Member States in invoking the ban on societal grounds while not limiting excessively the possible invocable grounds.

The above discussed change to the proposal to amend Directive 2001/18/EC would result in an unprecedented reform of the GMO authorization framework of the European Union through the introduction of societal grounds as possibly justifications for Member States to invoke limitations or restrictions on GMO cultivation. Therefore, due to the experimental nature of such a reform, we propose to include a sunset clause in the proposed Art. 26b, with a limitation period of ten years from the moment of the coming into force of the proposed amendment.

Apart from the fact, that the list is non-exhaustive in nature, and can potentially be extended in the future, there are stil two fundamental questions to be answered. Those questions relate to the 'Who' and 'How' of the assessment, i.e. who should be in charge of this assessment, and how the grounds mentioned in the list can be operationalized in order to be compatible for assessment?

\subsection{The Assessment Committee}

In our opinion, the task should be delegated to a committee, established under the framework of EFSA. We argue that at the European level, EFSA's role could be redefined by the inclusion of societal concerns. This Committee could provide quality judgment concerning the sufficiency of Member States' societal assessments for legal purposes. For the sake of substantiating the societal grounds, the enhancement of a better understanding of the Member States assessment of the socio-economic impact of GMO cultivation could also be a task of the committee. The creation of such a committee is arguably necessary as without it the functioning of the proposal could be prejudiced. Currently, there is no such entity that could provide sufficient guidelines concerning the invocation of societal grounds. Such an EFSA committee could provide guidelines concerning the acceptability of societal grounds as right now there is no such committee providing those guidelines. The Member States competent authority would forward their societal assessment on GMOs to that committee. Consequently, EFSA's committee would write a report on the basis of the individual Member States' societal reports and hand them to the Commission. The Commission would then regard the individual Member States' concerns. 


\subsection{Possible Assessment Practices}

After having clarified the issue of the entity responsible for the task of the assessment of invocable grounds, the next question to elaborate on, concerns the operationalization of the grounds in order to accomplish the assessment. Two examples are provided that could enhance the process of assessment, which are firstly based on a report of the European Commission and the Parliament, and secondly on the reporting practice of the Dutch Commissie Genetische Modificatie (COGEM).

A joined report from the European Commission and the Parliament from December 2009 indicates that "the understanding of the meaning and scope of the socioeconomic dimension of GMO cultivation varies widely among Member States and the stakeholders" ${ }^{142}$ Furthermore, the socio- economic implications "are often not analyzed in an objective manner". ${ }^{143}$ Therefore, it is necessary to establish systematic analytical guidelines, which clearly instruct on how to conduct the assessment and, even more important, which aspects shall be part of this assessment.

In recent decades, the importance of 'social impact assessment' (SIA) has increased. 'Social impacts' thereby refer to the consequences which affect the population due to a public or private action. This can relate to lifestyles, work, social relations, but also norms, values and belief systems. ${ }^{144}$ The SIA then can be defined as the attempt of an a priori examination of an event or policy action. Thus, attempting to give a prognosis on social implications. $^{145}$

The EU Impact Assessment Guidelines list thirty-five dimensions, which are related to Economics, Social Affairs and Environmental and Health Concerns. As the amendment proposal excludes grounds on environment and health, these dimensions cannot be part of a SIA. We identified ten dimensions in total (Table 1), which could be related to the cultivation of GMOs and grounds for a GMO ban.

142 Commission Report to the European Parliament and the Council on Socio-Economic Implications of GMO Cultivation on the Basis of Member States Contributions, as Requested by the Conclusions of the Environment Council of December 2008, COM(2011) final, at p. 3.

143 Commission Report on Socio-Economic Implications, supra note 142.

144 Commission Impact Assessment Guidelines, SEC(2009) 92, at p. 1.

145 COM Impact Assessment, supra note 144. 


\begin{tabular}{|c|c|c|c|c|}
\hline Internal Market & $\begin{array}{l}\text { Competitiveness, } \\
\text { trade }\end{array}$ & $\begin{array}{l}\text { Specific regions/ } \\
\text { sectors }\end{array}$ & $\begin{array}{l}\text { Employment/Labour } \\
\text { market }\end{array}$ & $\begin{array}{l}\text { Innovation and } \\
\text { Researchs }\end{array}$ \\
\hline Consumer choice & $\begin{array}{l}\text { Global competitive } \\
\text { position of EU }\end{array}$ & $\begin{array}{l}\text { Effect on certain } \\
\text { sectors }\end{array}$ & Job creation & $\begin{array}{l}\text { Stimulate/hinder } \\
\text { research }\end{array}$ \\
\hline Higher prices & Trade barriers & $\begin{array}{l}\text { Effect on certain } \\
\text { regions }\end{array}$ & Loss of jobs & $\begin{array}{l}\text { Technological } \\
\text { development }\end{array}$ \\
\hline Creation of barriers & $\begin{array}{l}\text { Crossborder } \\
\text { investment flows }\end{array}$ & $\begin{array}{l}\text { Disproportionally } \\
\text { affected region/MS }\end{array}$ & $\begin{array}{l}\text { Particular negative } \\
\text { consequences }\end{array}$ & Property rights \\
\hline $\begin{array}{l}\text { Anti-competitive } \\
\text { behaviour }\end{array}$ & & & Age groups & $\begin{array}{l}\text { Academic/Industrial } \\
\text { research }\end{array}$ \\
\hline \multirow[t]{2}{*}{$\begin{array}{l}\text { Market } \\
\text { segmentation }\end{array}$} & & & Demand for labour & $\begin{array}{l}\text { Productivity/ } \\
\text { Efficiency }\end{array}$ \\
\hline & & & $\begin{array}{l}\text { Functioning of } \\
\text { labour market }\end{array}$ & \\
\hline Macroeconomics & Culture & $\begin{array}{l}\text { Admin. burdens on } \\
\text { businesses }\end{array}$ & Consumers & $\begin{array}{l}\text { Third countries } \\
\text { effects }\end{array}$ \\
\hline Economic growth & $\begin{array}{l}\text { Impact on cultural } \\
\text { heritage }\end{array}$ & $\begin{array}{l}\text { Obligations placed } \\
\text { on businesses }\end{array}$ & Effect on prices & $\begin{array}{l}\text { Trade/Investment } \\
\text { flows }\end{array}$ \\
\hline $\begin{array}{l}\text { Conditions for } \\
\text { investment }\end{array}$ & Cultural diversity & $\begin{array}{l}\text { Impact on SMEs in } \\
\text { particular }\end{array}$ & $\begin{array}{l}\text { Benefit from } \\
\text { internal market }\end{array}$ & Specific groups \\
\hline $\begin{array}{l}\text { Proper functioning } \\
\text { of markets }\end{array}$ & $\begin{array}{l}\text { Access to cultural } \\
\text { resources }\end{array}$ & $\begin{array}{l}\text { Disproportionally } \\
\text { affected region/MS }\end{array}$ & $\begin{array}{l}\text { Availability/Quality } \\
\text { of goods }\end{array}$ & $\begin{array}{l}\text { International } \\
\text { standards, } \\
\text { Common regulatory } \\
\text { approaches }\end{array}$ \\
\hline \multirow[t]{4}{*}{$\begin{array}{l}\text { Macro-economic } \\
\text { stabilization }\end{array}$} & & & $\begin{array}{l}\text { Consumer } \\
\text { protection }\end{array}$ & $\begin{array}{l}\text { Effect on countries } \\
\text { with PTA }\end{array}$ \\
\hline & & & $\begin{array}{l}\text { Financial situation } \\
\text { of individuals }\end{array}$ & $\begin{array}{l}\text { Effect on developing } \\
\text { countries }\end{array}$ \\
\hline & & & & $\begin{array}{l}\text { Adjustment costs } \\
\text { on developing } \\
\text { countries }\end{array}$ \\
\hline & & & & $\begin{array}{l}\text { Effects on goods } \\
\text { and services } \\
\text { by developing } \\
\text { countries }\end{array}$ \\
\hline
\end{tabular}

One of the most important aspects is the compatibility of unilateral GMO bans on the Internal Market. As stated in the previous section, it is important that Member States, 
wishing to ban a GMO from cultivation on their territory, is in line with Article 26 TFEU, thus, the functioning of the Internal Market must not be distorted.

More difficult to assess is the possible negative effect on EU competitiveness as a whole, if a Member State or a group of Member States is willing to ban a GMO from cultivation. As the case of Monsanto, which plans to leave the European market, ${ }^{146}$ indicates, there can be adverse effects on the European Union's competitive position. It is not unlikely that more GM companies will follow Monsanto, leaving the EU as the only continent without GM cultivation. Investments into research and plants then also might be restrained. This dimension is closely linked with Macroeconomics and Employment.

The employment dimension relates to the creation or loss of jobs due to a certain policy measure. Applied to the case of GMOs, an SIA has to measure in how far jobs and employment opportunities are created or destroyed by GMO cultivation in a certain region or country. It might be the case that GMOs destroy traditional economic structures, or make it even impossible to grow non-GMO seeds, since it is practically impossible to prevent GM pollen to spread to non-GM plants. This is particularly troublesome with regard to organic farming, as the case of Austria demonstrates.

The regional dimension also takes into account that different European regions would be affected differently by GMO cultivation, due to geographical, agricultural and social factors. This aspect is decisive in the local populations' acceptance of GMO cultivation. The SIA should also take into account specific regional economic sectors, which can be affected. A further aspect is the cross-border effect of GMO cultivation in frontier areas, when a pro-GM country shares a border with a GM-free Member State.

In terms of innovation and research, it has to be assessed, whether a ban of GMOs might have adverse effects on terms of research in the EU and certain Member States. Many GM companies are research-intensive units. Again, the question has to be answered, whether bans might lead to an exodus of exactly those kinds of companies, which play an important role in the so-called future markets, such as bio-technology. Innovation is an important economic growth factor. This also relates to other objective the EU aims to pursue, such as the science and research strategy. ${ }^{147}$ In this respect, it is evenly important to take the broader macro-economic picture into account. Unilateral bans might worsen the conditions for investments and distort the functioning of markets, but also the

146 Zeit Online, "Monsanto stellt Genforschung in Europa ein", 31 May 2013, available on the Internet at: http://www.zeit.de/wissen/umwelt/2013-05/monsanto-gentechnik-saatgut.

147 Commission Communication on Europe 2020: A Strategy for Smart, Sustainable and Inc lusive Growth, $\operatorname{COM}(2010) 2020$, at p. 8. 
prospects of economic growth could be negatively affected, when certain industries are practically excluded from a countries' market.

The cultural dimension lacks clarity; however, it is conceivable that certain aspects of traditional agriculture are regarded as cultural heritage. It then has to be evaluated, in how far this is affected by GMO cultivation. Nevertheless, this remains an ambiguous issue. Another important aspect is the burden for companies, when cultivation is only possible in certain Member States. Due to differences in climate and landscape, not every country is eligible for cultivation of all seeds, so a GM company might not be able to shift cultivation to a pro-GM Member State. On the other hand, structural changes in European agriculture might include the growing dependence on large seed enterprises, such as Monsanto or Bayer.

Consumer protection is a decisive issue in food policy. In relation to GMOs this can include the availability of certain goods, as well as the effect on prices, when the market is dominated by certain companies or products. On the other hand, consumers should benefit from the internal market, thus, they should have a choice in deciding whether to buy and consume GM products, or not. This requires product safety, as well as quality of goods.

Finally, it should be assessed in which ways unilateral import bans might affect third countries. This concerns investment and trade flows, but also the adherence of international standards. With regard to GMOs third countries might be affected as being the new target countries for GM companies, as the cultivation in Europe is hindered. This could lead to a displacement of traditional agriculture in developing countries and an alteration of the national economic structure. Social problems in developing countries might be aggravated or social tensions evoked.

Another example for the possible assessment of grounds can be based upon the reporting practice of COGEM in the Netherlands. As an advisory body COGEM inter alia informs the Dutch government of "ethical and societal issues linked to genetic modification." ${ }^{178}$ In its topic reports "COGEM has analysed the GMO debate, reported on [the] societal consequences of new technological developments, and inadequacies in the GMO regulations" ${ }^{149}$ Such a COGEM "topic report" on societal concerns employs social sciences to analyze societal or ethical concerns. These include socio-economic, cultural and ethical implications of GMOs.

In summary, it can be stated that the amendment proposal is a significant progress. The creation of a separate unit assessing societal implication of GMOs seems necessary as without it, the proposal could not function. The proposal only contains a non-exhaustive list, which does

148 COGEM, "Home page”, available on the Internet at: http://www.cogem.net/index.cfm/en/cogem/.

149 COGEM, “Topic Reports”, available on the Internet at: http://www.cogem.net/index.cfm/en/activities/ topic -reports/. 
not provide sufficient clarity as to what exactly could be invoked. Thus, evoking the safeguard clause on socio-economic, cultural or ethical reasons by a Member State would constitute an act of national concern, if based on justifiable grounds, and no longer be a concern for the entire internal market. This would be a step to de-harmonize a policy area, GMO cultivation in this respect. Although, such a reform would be a novelty in the history of European integration, such a regulatory framework would acknowledge national diversity across the EU. However, it is important to operationalize the indicative grounds towards clear assessment variables, on which basis it is possible to evaluate the Member States' bans in a more systematic manner. The assessment should be performed by a committee, which is incorporated under EFSA's roof, but which is separated from the scientific assessment. Furthermore, we propose to introduce the changes for an experimental period of ten years, in which the new regime can be evaluated. Thus, we argue that the proposed changes discussed above do have the potential to provide a solution to the one aspect of the deadlock. Specifically, through the inclusion of grounds in Art.26b and the creation of an assessment agency, Member States could receive sufficient guidance for the invocation of non-scientific grounds. Therefore, the deadlock concerning the frequent reliance of Member States on the safeguard clause with claims of new scientific evidence could be if not altogether avoided, but at least limited.

\section{Accommodating Diversity - The Broader Picture}

Put in broader perspective, the proposed amendment described and justified in the last section does not present a certain and final solution to both. The Hydra-like nature of GMO authorization makes reforming very difficult and complex as various stakeholders mean various opinions to incorporate; furthermore, the inherent problems with science as an arbiter remain, similar to the immortal head of the Hydra. Nevertheless, the direct inclusion of societal concerns into the debate on GMO cultivation bans and the use of social sciences to measure and assess these concerns is an important step forward towards a risk regulation process that is closer to reality. ${ }^{1{ }^{\circ}}$ The increased demand for enclosing

150 Calls for such an inclusion inter alia by: Zurek, K. (2013), Regulating Food Trade in the Enlarged European Union, in Marjolein B.A. van Asselt, Esther Versluis \& Ellen Vos (eds.), Balancing between trade and risk: Integrating legal and social science perspectives, (London, UK: Routledge, 2013), pp.15 et sq9.; Ariane Königa, Harry A. Kuiperc, Hans J.P. Marvinc, et al., "The SAFE FOODS framework for improved risk analysis of foods", 21, Food Control, (2010), pp.1566 et sqq.; Marion Dreyer, Ortwin Renn, Shannon Cope, \& Lynn J, Frewer "Including social impact assessment in food safety governance", 21, Food Control, 2010, 1620 et sq9.; Vessela Hristova, "Accommodating National Diversity in GMO Regulation" in Marjolein B.A. van Asselt, Esther Versluis \& Ellen Vos (eds.), Balancing between trade and risk: Integrating legal and social science perspectives ,(London, UK: Routledge, 2013), pp.107 et sqq.; Mihail Kritikos, “Traditional risk analysis and releases of GMOs into the European Union: space for non- scientific factors?", 34, European Law Review, (2009), pp.405 et sq9. 
non-scientific grounds in the process of banning GMO cultivation by Member States and societal stakeholders (as shown by events such as global protests against Monsanto and the media coverage of these) $)^{151}$ corroborates that the amendment as such is important; the proposed changes hopefully facilitate to agree upon it.

Especially after the EU enlargements in 2004 and 2007, the EU comprises Member States with various different backgrounds and social structures. As argued above, a ban on cultivation also has repercussions on the internal market and trade concerns as GM seeds are an unpopular product if one cannot use them. Concerning the internal market, the "heterogeneity implies slightly different needs and is more difficult to manage", 152 being one more reason for Zurek, a legal scholar analysing the regulatory regime of EU food trade, to include socio-economic grounds and consequently increase embeddedness of the decision-making process. ${ }^{153}$

Hristova, a political scientist studying to what extent $\mathrm{GMO}$ regulation incorporates Member States' opinions, describes two ways of accommodating this present diversity: deliberation and differentiation. While it is attempted to consider scientific and nonscientific concerns of all stakeholders in the decision-making process through deliberation, differentiation steps in after the authorization of a certain GMO has taken place and allows Member States to abstain from the authorization. ${ }^{154}$ With the amendment proposal of the Commission, the latter seems to favour reforms in the direction of differentiation since Member States would be able to ban GMOs post-authorization. As our proposal is based on this approach, we deviate from Hristova's analysis. In contrast to her view, the de-

151 NOS, "Wereldwijd protest tegen Monsanto", 25 May 2012, available on the Internet at:http://nos.nl/ video/510739-wereldwijd- protest-tegen-monsanto.html (last accessed 30 May 2013); Hunffingtonpost,"March Against Monsanto' Protesters Rally Against U.S. Seed Giant And GMO Products", 25 May 2013, available on the Internet at: http://www.huffingtonpost.com/2013/05/25/march-against-monsanto-gmo-protest_n_3336627. html (last accessed on 30 May 2013); NY Daily News, "Monsanto protesters across globe rally against firm's genetically modified food products", 25 May 2013, available on the Internet at: http://www.nydailynews.com/ news/national/monsanto-protesters-globe-rally-firm-genetically-modified-food-products-article-1.1355457 (last accessed on 30 May 2013); Aljazeera, "Worldwide protests held against Monsanto", 26 May 2013, available on the Internet at http://www.aljazeera.com/news/americas/2013/05/2013525195352236439.html (last accessed on 30 May 2013); Leonie Sontheimer, “Märsche mahnen Monsanto", Die Tageszeitung, 25 May 2013, available on the Internet at http://www.taz.de/!11680o/ (last accessed on 6 June 2013).

152 Zurek, Regulating Food Trade in the Enlarged European Union, supra note 31, at p. 22.

153 It is also interesting to note that Zurek foresaw the second deadlock in a way: "There is a risk, however, that in order to get away from the transnational conflict, the EU will allow for new internal conflicts and internal EU regulatory fragmentation", ibid.

154 Hristova, "Between Politics and Science. Accommodating National Diversity in GMO Regulation", supra note 30. 
harmonisation and distribution of power back to the national level that might follow the proposal is not perceived as a negative consequence for the EU and the internal market. ${ }^{155}$

Risk regulation and possible cultivation bans are a trade issue also prevalent in the WTO context. In line with the argumentation of the legal scholar Weimer, current legal frameworks at WTO level forbid unnecessary trade restrictions, but also are already "recognised for being more generous in recognising the importance of certain values when weighed against the negative effects on trade". ${ }^{156}$ Additionally, inside the US internal market there already is the model example of the situation in which possible bans at state level are allowed, but that social concern at the higher level does not allow for a national ban. Although this is the case for the chemical Bisphenol A, the issue at stake still is risk regulation in the situation of uncertainty. ${ }^{157}$ In reference to the widespread concern in some Member States that cultivation bans might be a hindrance to the internal market, it might be more feasible to generally argue for a cal for 'free movement of most goods' in some sectors instead of the so far predominant notion of free movement of goods. This sector-by-sector approach would furthermore contrast a too strict and inflexible risk regulation, which in turn probably leads to a growing discontent in society. ${ }^{158}$ All this also relates back to the aim of the differentiation method by Hristova to accommodate diversity and different concerns of stakeholders.

The coexistence of natural and social sciences in this article's proposal also aims to shed more light into the bias of science in general. Similar to what was argued above, Weimer stresses that the nature of science is socially constructed and influences the evaluations excessively. ${ }^{159}$ Social science studies are also biased due to the importance of definitions of social impact and acceptable thresholds. ${ }^{160}$ On another note, risk regulation faces the struggle of political influences.

155 "Hristova warns that accommodating diversity will affect the constitutional characteristics of the EU, as it implies redistributing political authority", Van Asselt, M.B.A., Fox, T., Versluis, E., \& Vos, E. Regulating Innovation, Trade and Uncertain Risks. In Marjolein B.A. Van Asselt, Esther Versluis \& Ellen Vos (eds.), Balancing between trade and risk: Integrating legal and social science perspectives, (London, UK: Routledge, 2013), pp.15 et sq9, at p. 258

156 Weimer, “EU Risk Governance of 'Cloned Food”', supra note 33, at p.47

157 Fox, T., Versluis, E., \& van Asselt, M.B.A. (2013), Regulating the Use of Bisphenol A in Baby and Children's Products in the European Union, p. 159.

158 Zurek, Regulating Food Trade in the Enlarged European Union, supra note 31, at p. 22 \& p, 28.

159 Weimer, “EU Risk Governance of 'Cloned Food”, supra note 33, p. 49

160 Marion Dreyer, Ortwin Renn, Shannon Cope, \& Lynn J, Frewer, "Including social impact assessment in food safety governance", 21, Food Control, 2010, 1620 et sqq, at p. 1623. 
This is called de-politicisation,

a politicisation of the scientific executive function, which might (...) lead to obscure and insensitive decision making at the level of the simple application of science to complex social relations, and one which might (...) deny its own normative under-pinnings".

We think that the combination of both kinds of sciences is needed so that a) these biases become clearly acknowledged and communicated inside and outside of EFSA, also leading to more uncertainty tolerance and b) a justifiable and objective risk assessment is ensured. Without science, undesirable arbitrary risk regulation would be more probable as politics might be even more influential than it is now. ${ }^{162}$ Natural and social sciences thus are essential for improving the risk regulation process in the direction of more embeddedness and against an infeasible one-size- fits-all approach; ${ }^{163}$ in the attempt to come closer to a solution to the deadlock, it is therefore suggested that the diverse concerns are accommodated by differentiation and the inclusion of social sciences next to natural sciences.

\section{Conclusion}

In this article, we aim to analyse to what extent the two deadlocks in the authorization of GMO cultivation can be unlocked. The GMO authorization process is an allegoric Hydra as complex and various issues lead to continuous debates and blocking minorities in the decision-making procedure. Several current events present the GMO authorization as a hot topic: first, Monsanto declared to left the EU internal market due to the persistent banning of MON810 in some Member States; second, global protests against the same company have spread awareness of the topic and have shown the widespread concern of the public, and third, the Commission has announced to revive talks on a draft amendment of Directive 2001/18/EC.

This latter draft legislation aimed at solving the first deadlock, being the continuous and adamant invocation of the safeguard clause by Member States such as Austria, on the one hand, and the persistence on the illegality of those bans by EFSA and the Commission, on the other hand. The fact that not only Austria, but several others also banned MON810

161 Everson \& Vos, The scientification of politics and the politicisation of science, supra note 17, at p.6.

162 On the inherent political nature of risk assessment, see for example pp. 266-271.

163 Miriam Hartlapp, Gerda Falkner, Simone Leiber, Olive Treib, Complying with Europe: EU Harmonisation and Soft Law in the Member States, (Cambridge: Cambridge University Press, 2005). 
shows that the Member States do not trust EFSA's risk assessment entirely based on natural sciences, that GMOs are safe. Main reasons for this mistrust is scientific uncertainty and the existence of scientific studies differing in their evaluations of risks. As different science and technology scholars argue, science is no value-free arbiter as different methods and research questions result in different outcomes. Another problem described in our section on science is that risk managers at the EU level mainly argue in line with risk assessment without reflecting on scientific bias. Furthermore, non-risk grounds such as moral, ethical or socio-economic related ones are major reasons for some of the bans and especially for the high sensitivity of the debate. These several problems faced in the GMO authorization process can allegorically be seen as the numerous heads of the hydra. Whereas in mythology Herakles managed to defeat the Hydra after several attempts, this is still an ongoing battle at the EU level as the Commission, sometimes together and sometimes against the Member States, tries to solve all the problems.

Focusing on the problem with risk issues, the Member States urged the Commission to propose the amendment which would enable bans based on non-risk grounds. However, a minority of Member States blocked the decision-making in the Council by reasoning with two substantive legal objections. First, it is assumed that the bans would hinder the internal market under Article 34 and needed to be justified under Article 36 of the TFEU. Second, opposing Member States argued with non-existent WTO compatibility. In our analysis, it is however made clear that both concerns are not appropriate as long as proper justifications for the bans are given. Based on both analyses, we propose a) an exhaustive list of grounds in order to safeguard legal certainty, b) the inclusion of a social impact assessment to guarantee non-arbitrary bans on non- risk grounds, and c) the establishment of an assessment committee as part of EFSA. The particular task of this committee is to ensure the evaluation of the assessments based on social sciences. As we are aware of the struggle to reform this complex policy domain, we argue for a sunset clause in the amendment to allow for continuous improvement of the regulatory procedure.

It also needs to be recognized that this proposal is a first step forward to accommodating diversity by the method of differentiation. Acknowledging the limits of science and expanding its scope at the same time, we hope that if results and issues of both natural and social sciences are discussed, the problems of scientific bias and uncertainty can be taken into account. It is interesting to see how the situation of the two deadlocks develops in the future. More research should be conducted to investigate on how social sciences can be included in the future authorization process of GMOs in the context of EU risk regulation and the already established agencies. Moreover, it is worth observing the contemporary tensions surrounding the GMO debate such as Monsanto leaving the European market, two-thirds of the European public opposing GMOs and whether new problems arise. 


\section{References}

\section{Books}

Ulrich Beck, Risk Society: Towards a New Modernity (London: Sage, 1992), pp.166-68.

Miriam Hartlapp, Gerda Falkner, Simone Leiber, Olive Treib, Complying with Europe: EU Harmonisation and Soft Law in the Member States, (Cambridge: Cambridge University Press, 2005)

Sheila Jasanoff, Designs on Nature: Science and Democracy in Europe and the United States, (USA: Princeton University Press, 2005).

\section{Edited Volumes}

Michel e Everson \& El en Vos, "The Scientification of Politics and the Politicisation of Science", in Michel e Everson \& El en Vos (eds.), Uncertain Risks Regulated. Facing the Unknown in National, EU and International Law. (London and New York: Routledge, 2009), pp.1-17.

Elizabeth Fisher, Judith Jones \& René von Schomberg, (eds), Implementing The Precautionary Principle - Perspectives and Prospects, (UK: Edward Elgar Publishing Limited, 2006).

Tessa Fox, Esther Versluis \& Marjolein B.A. Van Asselt, "Regulating the Use of Bisphenol A in Baby and Children's Products in the European Union: Trade Implications of an Uncertain Risk" in: in Marjolein B.A. van Asselt, Esther Versluis, \& Ellen Vos (eds.), Balancing between trade and risk: Integrating legal and social science perspectives, (London, UK: Routledge, 2013), pp.147 et sqq. Hristova, V. (2013), Accommodating National Diversity in GMO Regulation. In Marjolein B.A. van Asselt, Esther Versluis \& Ellen Vos (eds.), Balancing between trade and risk: Integrating legal and social science perspectives, (London, UK: Routledge, 2013), at p.110.

Anne-May Janssen \& Marjolein van Asselt, "The Precautionary Principle in Court - An Analysis of Post-Pfizer Case Law”, in Marjolein B.A. van Asselt, Esther Versluis \& El en Vos (eds.), Balancing between trade and risk: Integrating legal and social science perspectives, (London, UK: Routledge, 2013), pp.197 et sqq., et p.197.

Maria Lee, EU Regulation of GMOs. Law and Decision Making for a New Technology. (Cheltenham: Edward Elgar, 2009).

Marjolein B.A. van Asselt, Esther Versluis, \& Ellen Vos (eds.), Balancing between trade and risk: Integrating legal and social science perspectives, (London, UK: Routledge, 2013). 
Marjolein B.A. van Asselt, Tessa Fox, Esther Versluis \& El en Vos, "Regulating Innovation, Trade and Uncertain Risks", in Marjolein B.A. van Asselt, Esther Versluis, \& El en Vos (eds.), Balancing between trade and risk: Integrating legal and social science perspectives, (London, UK: Routledge, 2013), pp.247 et sqq. at p.248.

Marjolein B.A. Van Asselt, El en Vos \& B. Rooijackers, "Science, Knowledge and Uncertainty in EU Risk Regulation", in Michelle Everson \& Ellen Vos (eds.), Uncertain Risks Regulated. Facing the Unknown in National, EU and International Law. (London and New York: Routledge, 2009), pp.1-17.

Weimer, M. (2013), EU Risk Governance of 'Cloned Food'. In van Asselt, M.B.A., Versluis, E. \& Vos, E.: Balancing Trade and Risk, - Integrating Legal and Social Perspectives, p.47

\section{Journal Articles}

Susan Carr \& Les Levidow, "Exploring the Links Between Science, Risk, Uncertainty, And Ethics In Regulatory Controversies About Genetically Modified Crops", 2, Journal of Agricultural and Environmental Ethics, (2000), pp.29 et sqq., et p.32

Devos, Y., Maeseele, P., Reheul, D., Van Speybroeck, L., \& De Waele, D.; Ethics in the societal Debate on Genetically modified organisms: A (re)quest for sense and sensibility. Journal of Agricultural and Environmental Ethics 21, 2008, pp. 29-61.

Marion Dreyer, Ortwin Renn, Shannon Cope, \& Lynn J, Frewer, “Including social impact assessment in food safety governance", 21, Food Control, 2010, 1620 et sq9

Antonia Eliason, "Science versus Law in WTO Jurisprudence: The (Mis)interpretation of the Scientific Process and the (In)sufficiency of Scientific Evidence in EC-Biotech", 41, International Law and Politics (2009), 41, pp.341-406

Caroline Henckels, "GMOs in the WTO: A Critique of the Panel' Reasoning in the EC - Biotech", 7 , Melbourne Journal of International Law (2009), pp. 279-305;

Sheila Jasanoff, "Bridging the Two Cultures of Risk Analysis", 13, Risk Analysis (1993), et p.123. Jinhee Kim, Christoph Klika, \& Esther Versluis, "Agencies as Risk Managers? Exploring the role of EU agencies in authorization procedures", in Marjolein B.A. van Asselt, Esther Versluis \& Ellen Vos (eds.), Balancing between trade and risk: Integrating legal and social science perspectives, (London, UK: Routledge, 2013), pp. 175 et sqq;; at p.191.

Guy R. Knudsen, “Where's the Beef? How Science Informs GMO Regulation And Litigation”, Idaho Law Review 48, pp. 225-250, et p.230.

Mihail Kritikos, "Traditional risk analysis and releases of GMOs into the European Union: space for non- scientific factors?", 34, European Law Review, (2009), pp.405 et sqq. 
Ariane Königa, Harry A. Kuiperc, Hans J.P. Marvinc, et al.,"The SAFE FOODS framework for improved risk analysis of foods", 21, Food Control, (2010), pp.1566 et sqq.

Shane H.Morris \& Charles Spil ane, "EU GMO Crop Regulation:A Road to Resolution or a Regulatory Roundabout?" (2010), 4, European Journal of Risk Regulation, pp.359 et sqq.

Elina Paulino, "Beyond Predictability - Reflections on Legal Certainty and the Discourse Theory of Law in the EU Legal Order", 10, German Law Journal (2009), pp. 1469 et sqq.,at p. 1469.

John Rossi, “The Prospects of Objectivity in Risk Assessment”, 46, J Value Inquiry (2012), pp. 237 et sqq. Jacqueline Peel, Rebecca Nelson and Lee Godden, "GMO Trade Wars: The Submissions in the EC - GMO Dispute in the WTO”, 6, Melbourne Journal of International Law (2005), pp.141- 166;

Joachim Scholderer, “The GM foods debate in Europe: History, regulatory solutions, and consumer response research", 5, Journal of Public Affairs, (2005), pp. 263-274, p. 267-the Member States were Denmark, France, Greece, Italy and Luxembourg.

Marjolein B.A. van Asselt \& El en Vos, "Wrestling with Uncertainty: EU Regulation of GMOs and the Uncertainty Paradox", 11, Journal of Risk Research, 2008, pp. 281-300

Marjolein B.A. Van Asselt \& Ortwin Renn, "Risk Governance", 14, Journal of Risk Research, pp.431 et sqq., at p.438

Marjolein B.A. Van Asselt \& El en Vos, "The Precautionary Principle and the Uncertainty Paradox", 9, Journal of Risk Research (2006), pp.313 et sqq.

-- "Wrestling with uncertain risks: EU regulation of GMOs and the uncertainty paradox", 11, Journal of Risk Research, (2008), pp.281 et sqq.

Maria Weimer, "What Price Flexibility? - The Recent Commission Proposal to Allow for National "Opt-Outs" on GMO Cultivation under the Deliberate Release Directive and the Comitology Reform Post-Lisbon", 4, European Journal of Risk Regulation (2010), pp.345 et sqq.

Fern Wickson \& Brian Wynne, "The Anglerfish deception - The light of proposed reform in the regulation of GM crops hides underlying problems in EU science and governance", 13, European Molecular Biology Organization Reports, (2012), pp.100 et sqq.

"Ethics of Science for Policy in the Environmental Governance of Biotechnology: MON810 Maize", 15, Europe, Ethics, Policy \& Environment, (2012), pp. 321 et sqq.

David Winickoff, Sheila Jasanoff, Lawrence Busch et al., "Adjudicating the GM Food Wars: Science, Risk, and Democracy in World Trade Law", 30, The Yale Journal of International Law (2005), pp.82-123.

Brian Wynne, "Elephants in the room where publics encounter 'science'?: A response to Darrin Durant 'Accounting for expertise: Wynne and the autonomy of the lay public"' in 17, Public Understanding of Science, (2008), pp. 21 et sqq

Karolina Zurek, "Indicating Reasons for National GM “Opt-Outs": The Way Forward or a Dead End Street?", 2 European Journal of Risk Regulation (2011), pp. 241 et sqq., at p. 243. 
"Regulating Food Trade in the Enlarged European Union", in Marjolein B.A. van Asselt, Esther Versluis \& Ellen Vos (eds.), Balancing between trade and risk: Integrating legal and social science perspectives, (London, UK: Routledge, 2013)

\section{International Documents \& Legislation}

Bundesgesetzblatt für die Republik Österreich, Teil II:Verordnungen, 1999. 175. Verordnung:Verbot des Inverkehrbringens des genetisch veränderten Maises Zea Mays L., Linie MON 810, in Österreich.

Bundesministerium für Ernährung, Landwirtschaft und Verbraucherschutz, (2009). Press release no. 063 from 14.04.2009: Aigner prohibits cultivation of MON810. Available on the Internet http://www.bmelv.de/SharedDocs/Pressemitteilungen/EN/O63-MON810.html (last accessed on 14 June 2013).

Bundesministerium für Gesundheit und Frauen (1999). Gründe für die Entscheidung der Republik Österreich, das Inverkehrbringen der gentechnisch veränderten Maislinie MON810, notifiziert von der Fa. Monsanto Europa SA gemäß der Richtlinie 90-220/EWG und zugelassen von der Französischen Republik am 5. August 1998, zu verbieten. Available on the Internet et http://bmg.gv.et/cms/home/attachments/2/2/5/CH106o/CMS1212741055132/mon810_ begruendung.pdf (last accessed on 14 June 2013), et pp. $2-4$.

Bundesamt für Verbraucherschutz und Lebensmittelsicherheit (2009). Stellungnahme der ZKBS zur Risikobewertung von MON810 - Neue Studien zur Umweltentwicklung von MON810. Available on the Internet at fhttp://www.bvl.bund.de/SharedDocs/Downloads/06_Gentechnik/ZKBS/01 Allgemeine_Stellungnahmen_deutsch/04_Pflanzen/MON810_Neubewertung_2009. pdf?blob=publicationFile\&v=3 (last accessed on 14 June 2013).

Michael Eckerstdorfer, Andreas Heissenberger \& Helmut Gaugitsch, Supplementary Risk Assessment for GM Maize MON810 with regard to the conclusions of the WTO-Panel in the case "EC Biotech" on Austrian safeguard measures for GM Maize, (Wien: Bundesministerium für Gesundheit, Familie und Jugend, Sektion IV, 2007).

World Trade Organisation (2006). European Communities - Measures Affecting the Approval and Marketing of Biotech Products (WT/DS291/R, WT/DS292/R, WT/DS293/R). Reports of the Panel. available on the Internet at: http://www.worldtradelaw.net/reports/wtopanelsfull/ecbiotech(panel)(full).pdf (last accessed on 14 June 2013). 


\section{European Union Documents \& Legislation}

Case C-120/95, Decker 1998 ECR 1831, at para. 39.

Case C-165/08, Commission of the European Communities v Republic of Poland [2009] ECR I- 6843 .

Commission Communication on Europe 2020: A Strategy for Smart, Sustainable and Inclusive Growth, $\operatorname{COM}(2010) 2020$

Commission Impact Assessment Guidelines, SEC(2009) 92.

Commission Report to the European Parliament and the Council on Socio-Economic Implications of GMO Cultivation on the Basis of Member States Contributions, as Requested by the Conclusions of the Environment Council of December 2008. Brussels, COM(2011) final.

Commission Staff Working Document on the Complementary Considerations on Legal Issues on GMO Cultivation Raised in the Opinions of the Legal Service of the Council of the European Union of 5 November 2010 and on the Legal Service of the European Parliament on 17 November 2010 (Indicative List of Grounds for Member States to Restrict or Prohibit GMO Cultivation), SEC (2011) 184 final, et p. 2.

Commission Staff Working Document on the Considerations on Legal Issues on GMO cultivation raised in the opinion of the Legal Service of the Council of the European Union of 5 November 2010, SEC(2010) 1454 final, et p. 3.

Commission Proposal for a Regulation of the European Parliament and of the Council Amending Directive 2001/18/ EC as regards the possibility for the Member States to restrict or prohibit the cultivation of GMOs in their territory, $\operatorname{COM}(2010) 380$ final, $\operatorname{COM}(2010) 4822$ final.

Council of the European Union, "Genetically Modified Organisms - A Way Forward"; 23 June 2009, available on the Internet: http://register.consilium.europa.eu/pdf/en/og/st11/st11226- reo1. eno9.pdf (last accessed on 14 June 2013).

Council of the European Union Cover Note on the Complementary Considerations on Legal Issues on GMO Cultivation Raised in the Opinions of the Legal Service of the Council of the European Union of 5 November 2010 and of the Legal Service of the European Parliament of 17 November 2010, 16826/10.

Council Press Release of the 3152nd Environment Council Meeting, 7478/12, et p. 11. Council Press Release of the 3075th Council Meeting, $7689 / 11$, et p. 8.

Council of the European Union "I/A" Item Note on the Proposal for a Regulation of the European Parliament and of the Council amending Directive 2001/18/EC as Regards the Possibility for the Member States to Restrict or Prohibit the Cultivation of GMOs in Their Territory, $108883 / 1 / 12$, et $p .5$. 
Council of the European Union Proposal for a Regulation of the European Parliament and of the Council amending Directive 2001/18/EC as Regards the Possibility for the Member States to Restrict or Prohibit the Cultivation of GMOs in their Territory - Preparation for the Informal Trialogue. 20010/0208 (COD) 10532/11.

Council of the European Union Proposal for a Regulation of the European Parliament and of the Council Amending Directive 2001/18/EC as Regards the Possibility for the Member States to Restrict or Prohibit the Cultivation of GMOs in Their Territory-State of play. 2010/0208 (COD), 17634/11.

Council of the European Union Proposal for a Regulation of the European Parliament and of the Council Amending Directive 2001/18/EC as Regards the Possibility for the Member States to Restrict or Prohibit the Cultivation of GMOs in their Territory - Revised Compromise Proposal in View of a Council Political Agreement (First Reading). 2010/O208 (COD) 7153/12.

DG Health and Consumers, "Rules on GMOs in the EU - Ban on GMO cultivation", no date, available on the Internet at http://ec.europa.eu/food/food/biotechnology/gmo_ban_cultivation en.htm (last accessed on 14 June 2013).

European Parliament and Council Directive 2001/18/EC on the deliberate release into the environment of genetically modified organisms and repealing Council Directive 90/220/EEC, OJ 2001 L 106.

European Parliament and Council Regulation (EC) No 178/2002 on the general principles and requirements of food law, establishing the European Food Safety Authority and laying down procedures in matters of food safety, OJ L 031, 1.2.2002, p.1.

Kommission, Entscheidung der Kommission über das vorübergehende Verbot der Verwendung und des Verkaufs von genetisch verändertem Mais (Zea mays L., Linie MON810) gemäß der Richtlinie 2001/18/EG des Europäischen Parlaments und des Rates in Österreich, K (2008) 1718.

Corrine Lepage, Report on the proposal for a regulation of the European Parliament and of the Council amending Directive 2001/18/EC as regards the possibility for the Member States to restrict or prohibit the cultivation of GMOs in their territory (COM (2010)0375-C/-0178/2010 -2010/0208(COD)), Report issued by European Parliament on 20 April 2011.

TNS Opinion \& Social, "Special Eurobarometer 341 on Biotechnology”, October 2010, Document requested and coordinated by the European Commission DG Communication available on the Internet at http://ec.europa.eu/public_opinion/archives/ebs/ebs_341_en.pdf (last accessed 14 June 2013). 


\section{Newspaper Articles and Other News Items}

Aljazeera, "Worldwide protests held against Monsanto", 26 May 2013, available on the Internet http://www.aljazeera.com/news/americas/2013/05/2013525195352236439.html (last accessed on 30 May 2013)

COGEM, "Home page", available on the Internet at: http://www.cogem.net/index.cfm/en/ cogem/

, "Topic Reports", available on the Internet at: http://www.cogem.net/index.cfm/en/ activities/topic-reports/.

EurActiv, "EU wants to put GMO dispute to an end", 5 November 2010, available on the Internet at http://www.euractiv.com/cap/eu-wants-put-gmo-dispute-news-496059, (last accessed on 13 June 2013).

"EU move to break GM deadlock could sow discord", 5 November 2012, available on the Internet at http://www.euractiv.com/cap/eu-move-break-gm-deadlock-sow-di-news495753 (last accessed on 13 June 2013).

"EU GMO proposals draw widespread criticism", 5 November 2012, available on the Internet at http://www.euractiv.com/cap/eu-gmo-proposals-draw-widespread-news-496263 (last accessed on 13 June 2013).

- "Disgruntled GMO firms start pul ing out of EU market", 25 January 2012, available on the Internet at http://www.euractiv.com/cap/disgruntled-gmo-firms-start-pull-news-510378 (last accessed on 12 June 2013).

-_GMO debate continues to divide EU", 15 April 2013, available on the Internet et http:// www.euractiv.com/climate-environment/gmo-debate-continues-divide-eu-news-219382 (last accessed on 14 June 2013).

EurActiv.com with Reuters, “Danes Seek Compromise on GM Crops", 3 February 2012, available on the internet et http://www.euractiv.com/cap/danes-seek-compromise-gm-crops- news510562 (last accessed on 13 June 2013).

EurActiv, "Bulgaria approve law to ban GMO crops", 5 November 2012, available on the Internet at: http://www.euractiv.com/cap/bulgaria-approves-law-ban-gmo-cr-news-355729 (last accessed on 4 June 2013)

GMO-free regions 2012, "Austria", no date, available on the Internet http://www.gmo-freeregions.org/gmo- free-regions/austria.html (last accessed on 6 June 2013).

2012, "GE cultivation bans in Europe", no date, available on the Internet at: http:// www.gmo- free-regions.org/gmo- free-regions/bans.html (last accessed on 4 June 2013 
Hunffingtonpost, "March Against Monsanto' Protesters Rally Against U.S. Seed Giant And GMO Products", 25 May 2013, available on the Internet et: http://www.huffingtonpost. com/2013/05/25/march-against-monsanto-gmo-protest_n_3336627.html (last accessed on 30 May 2013)

Leonie Sontheimer, “Märsche mahnen Monsanto”, Die Tageszeitung, 25 May 2013, available on the Internet at http://www.taz.de/!116800/ (last accessed on 6 June 2013).

Merkur Online, "Bayern bremst grüne Gentechnik", 9.August 2010, available on the Internet et: http://www.merkur-online.de/aktuelles/politik/bayern-bremst-gruene-gentechnikmm-871416.html, (last accessed on 14 June 2013).

NY Daily News, "Monsanto protesters across globe rally against firm's genetically modified food products", 25 May 2013, available on the Internet et: http://www.nydailynews.com/ news/national/monsanto-protesters-globe-rally-firm-genetically-modified-food-productsarticle-1.1355457 (last accessed on 30 May 2013);

Reuters, "EU seeks to revive talks on GMO crop cultivation",22 January 2013 available on the Internet at http://uk.reuters.com/article/2013/o1/22/eu-gmo-cultivation- idUKL6NoARCX620130122 (last accessed on 6 June 2013).

Christian Schwägerl, "Gentechnik: Hier geht es um den Heimatbegriff”, 17 October 2010, available on the Internet et http://www.spiegel.de/politik/deutschland/gentechnik-hier-geht-es- umden-heimatbegriff-a-723550.html (last accessed on 5 June 2013).

Zeit Online, "Monsanto stel t Genforschung in Europa ein", 31 May 2013, available on the Internet at: http://www.zeit.de/wissen/umwelt/2013-05/monsanto-gentechnik-saatgut. 
